DOI:

$10.3927 / 51689233$

\title{
Document Version
}

Other version

Link to publication record in Manchester Research Explorer

\section{Citation for published version (APA):}

Pormann, P., Karimullah, K., Carpentieri, N., Mimura, T., Selove, E., Das, A., Obaid, H., \& Masry, S. (2017). University of Manchester. https://doi.org/10.3927/51689233

\section{Citing this paper}

Please note that where the full-text provided on Manchester Research Explorer is the Author Accepted Manuscript or Proof version this may differ from the final Published version. If citing, it is advised that you check and use the publisher's definitive version.

\section{General rights}

Copyright and moral rights for the publications made accessible in the Research Explorer are retained by the authors and/or other copyright owners and it is a condition of accessing publications that users recognise and abide by the legal requirements associated with these rights.

\section{Takedown policy}

If you believe that this document breaches copyright please refer to the University of Manchester's Takedown Procedures [http://man.ac.uk/04Y6Bo] or contact uml.scholarlycommunications@manchester.ac.uk providing relevant details, so we can investigate your claim.

\section{OPEN ACCESS}




\section{المقالة السسادسـة1}

] K1, T: بسم الله الرحمن الرحيم المقالة السـادسة CB2, Q1. 1 المقالة السادسة 


\section{] 264 [صل رقم ]}

قال أبقراط: إذا حدث الجشاء الحامض في العلة التي يقال لهها

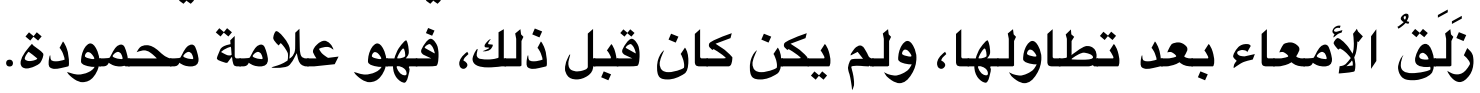

قال عبد اللطيف: زلق الأمعاء هي العلة التي يخرج فيها الطعام والثراب

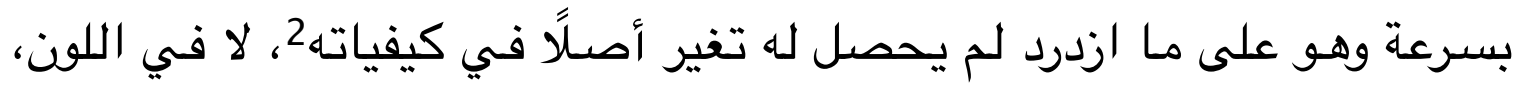

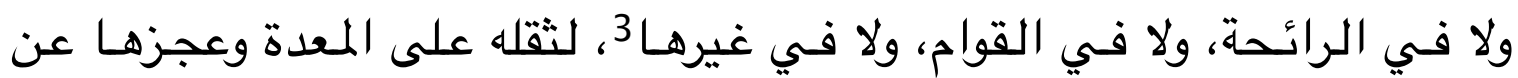

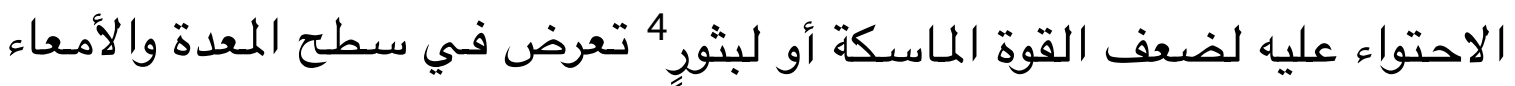

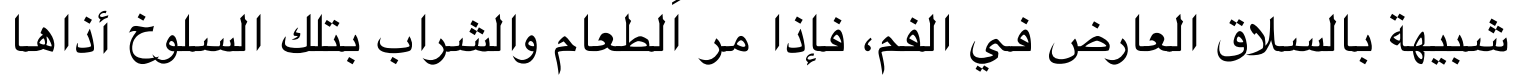

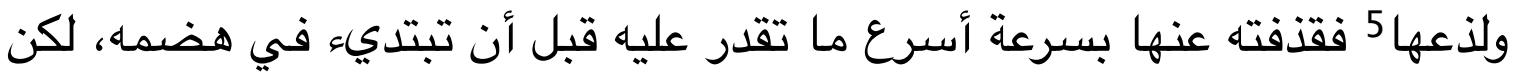

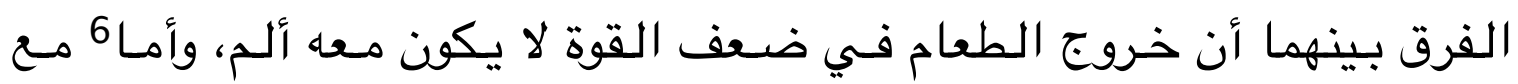

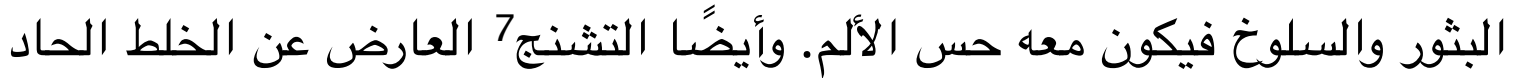

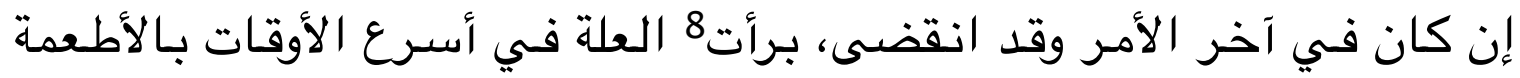

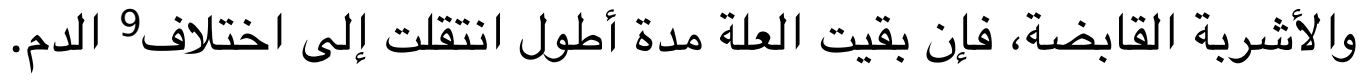

وأمـا الصنف الآخر الكائن من ضعف القوة الماسكة بسبب مزاج رديء

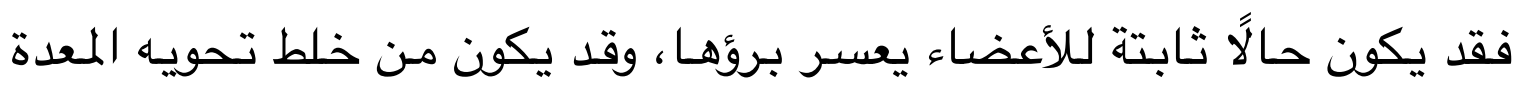

كيفيات : كيفياته Q 2 ] MSS.

[ غيره K1 MSS: غيره K1.

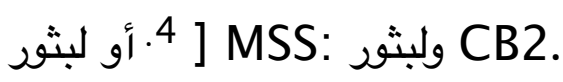

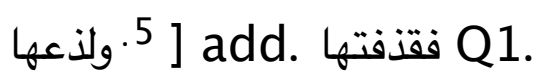

[ 6 ] MSS: om. K1.

MSS.

[برأه Q برأه Q1.

MSS. 
والأمعاء، وقد يكون ذلك الخلط بلغمًا حامضًا، وقد يكون غيره من الأخلاط. وقد

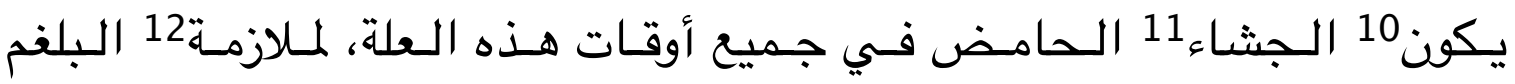

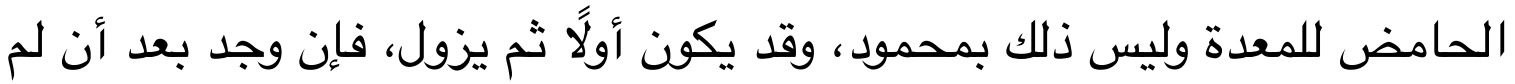

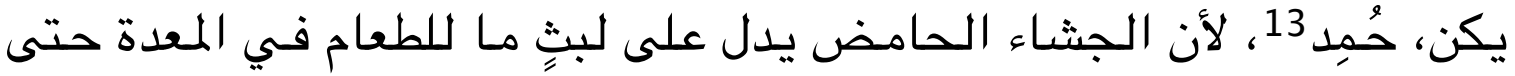

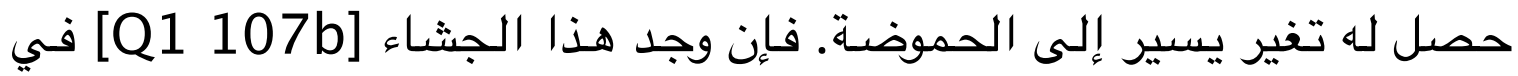

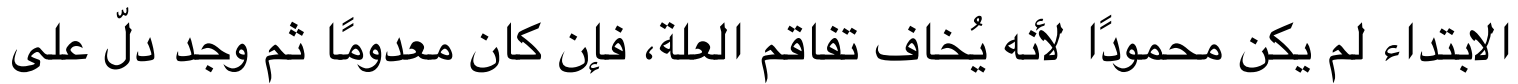

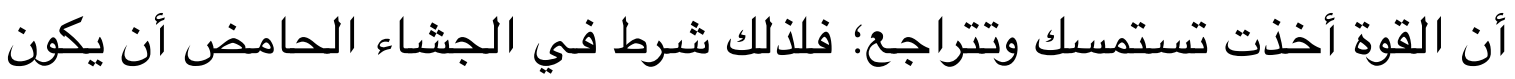

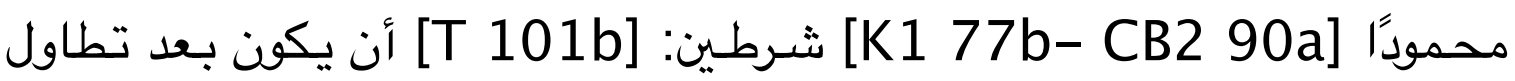

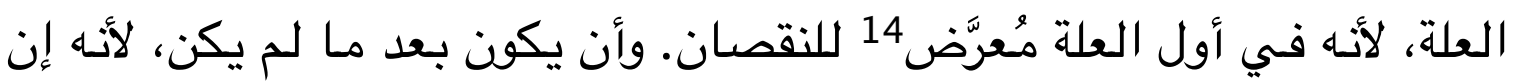

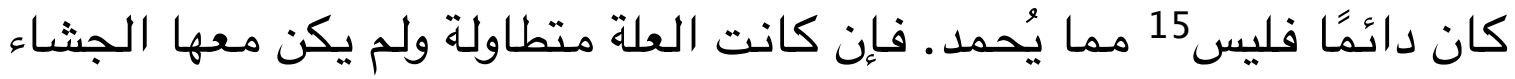

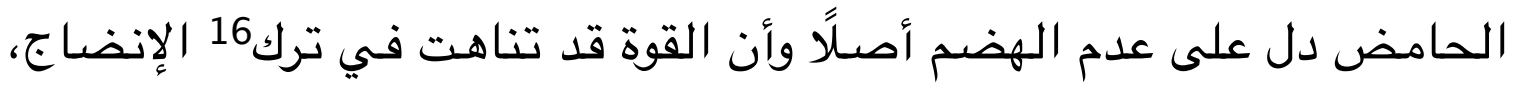
فإذا عرض الجثاء الحامض أذِن بالتراجع ويسير الهضم، ورُجي البرء.

\section{]}

قال أبقراط: من كان في منخريـه بالطبع رطوبة أزيد، وكان مَنِيُّة

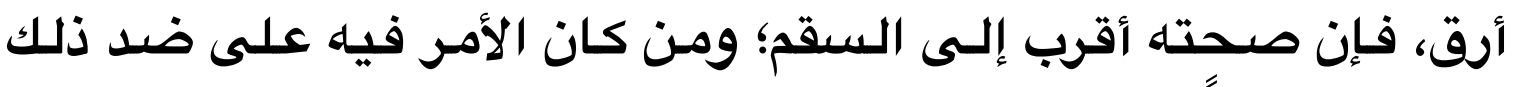

] 10 ] MSS: om. K1.

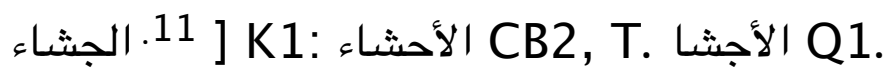

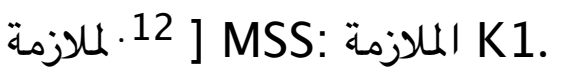

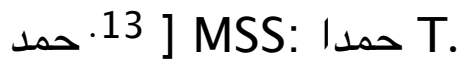

مرض T. 14 ] معرض MSS.

T.

ترك ] MSS: نزل CB2. 
قال عبد اللطيف: يقول من كان مزاجه رطبًا فبدنه كثير الفضول والامتلاء، قليل التحلل، سـريع الانفعال، وهـا حكم كل رطب. واستـل على على رطويـة المزاج

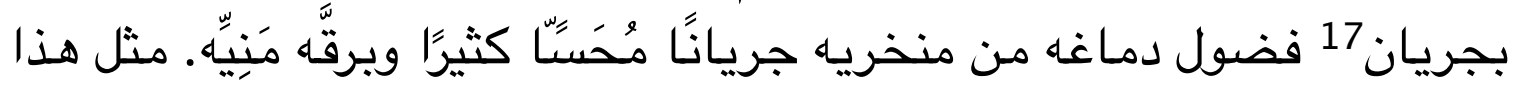

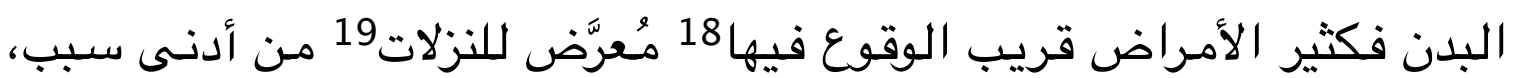

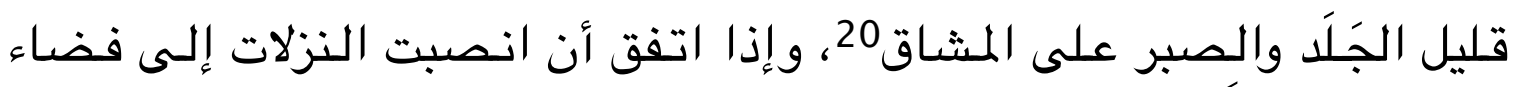

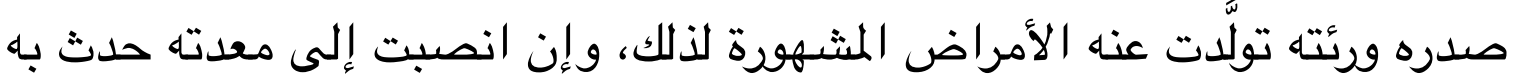

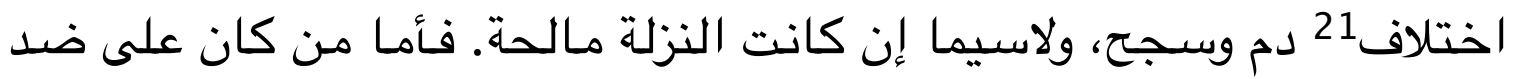

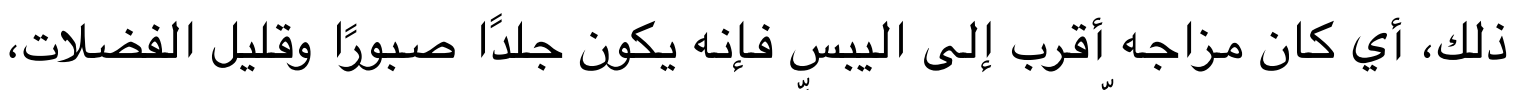

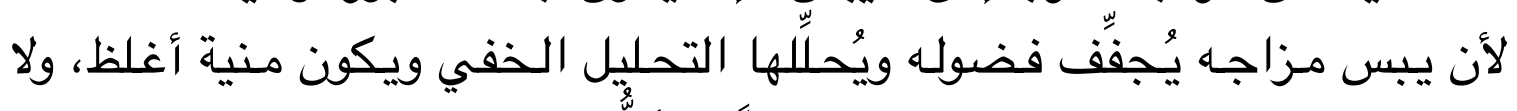

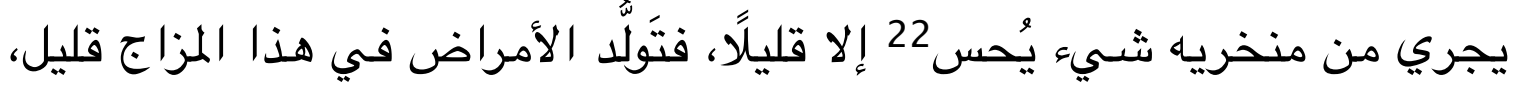
فلذلك يكون حاله أصلح.

وقوله: "مـن كان فـي منخريـه بـالطبع رطويـة أزيد" يـتمل أن يكون ذلك مزاجًا [Q1 108a] لسائر أعضائه، ويحتمل أن يكون لدماغه خاصة.

\section{]}

\section{قـال أبقراط: الامتناع مـن الطعام فـي اختلانف الـدم المزمـن دليل رديء، وهو مع الحمىى أردأ. قال عبد اللطيف: اختلاف الدم يكون أولًا عن أخلاط لذَّاعة تنصبّ إلىى}

] بكS: بأن K1.

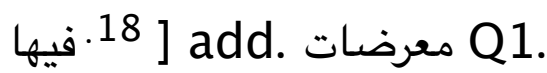

] MSS: للزلات T. 20 ] MSS: om. T. ] الاختلاف K K1. محس : 22 KSS. 
الأمعاء فتجردهـا ثم تسحجها ، فإذا تمادى الزمان غار العفن 23 في جرم المعا

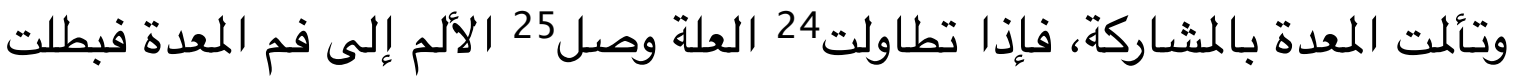

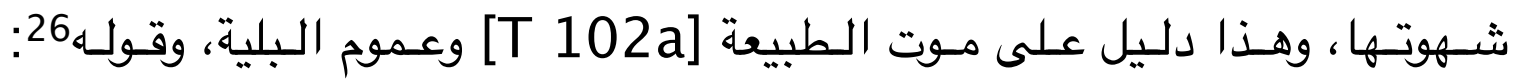
"الامتناع من الطعام" يريد 27 سقوط الثهـوة.

وقوله: "فـي اختلاف الدم المـزمـن" يـريـ المتطاول. [CB2 90b] قوله: "وهو مـ الحمى أردأ" لأن الحمى التابعة لهذا دليل على تقيح وتآكل، أو على 28 ورم عظيم فـي الأمـاء، وكل ذلك رديء مـع رديء فيكون أردأ. وقد تبطل شـهـوة

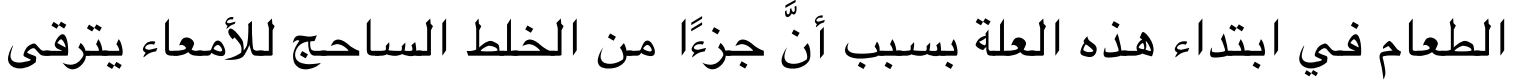
إلى المعدة فيلذعها ويؤلمها فتمتنع عن29 الطعام، لكن ذلك [K1 78a] مما يقبل البرء ولا يدل على موت الطبيعة.

\section{]}

\#تال أبقراط: مـا كان من القروح يتنثر ويتساقط مـا حوله، فهو خبيث30.

العقر . القعر : CB2, T.

] MSS: تطالت Q24. تطاولت Q1.

K 25 ] MSS: ووصل K1.

26 [قوقله MSS: فقوله K1.

27 ] MSS: يزيد K1.

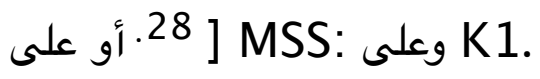

29 ] MSS: من K1.

30 ] MSS: om. Q1. 
قال عبد اللطيف: قوله31: "يتتثر ويتساقط" يريد به الشعر الذي حهل

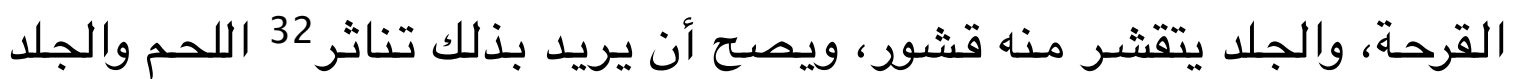

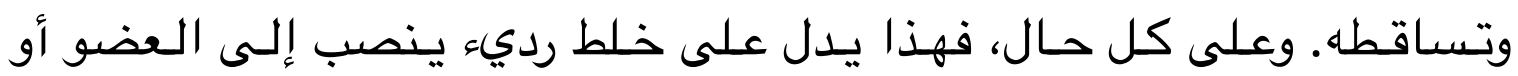

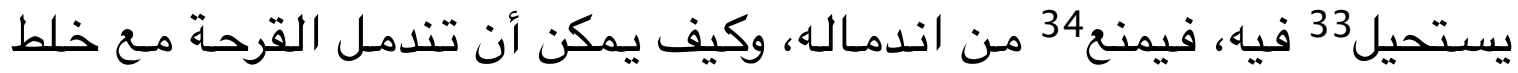
يأكلها ويوسِّعها ويزيد فيها.

\section{]}

قال أبقراط: ينبغي أن يتفقد من الأوجـاع العارضسة في الأضسلاع ومقدم الصدر، وغير ذلك من سائر الأعضاء، عظم اختلافها.

قال عبد اللطيف:ينبفي أن لا يُقتصر على تعرّف موضـح الوجع دون أن

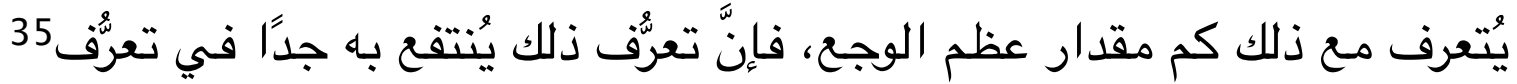

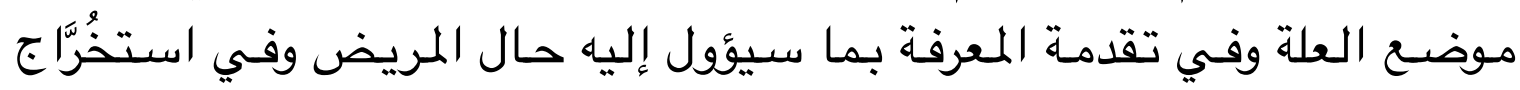

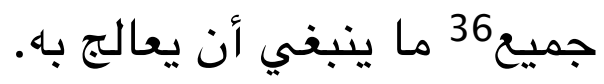

مثاله: أنه إذا عرض [Q1 108b] في الأضسلاع37 وجع عظيم، دل على

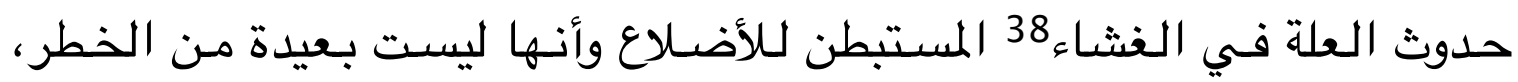

31 ] MSS: om. Q1.

32 ] MSS: تنتاثر T.

ويستحيل : و 33 أو يستحيل K1.

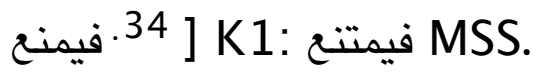

35 ] MSS: om. K1.

36 36 ] Mميع

J الأوضاع : MSS. الأضلاع T.

38 ] MSS: om. K1. الفشاء 
وأنها39 تحتاج من العلاج إلى ما هو أقوى وأعظم، فإن كان الوجع يتراقى إلى

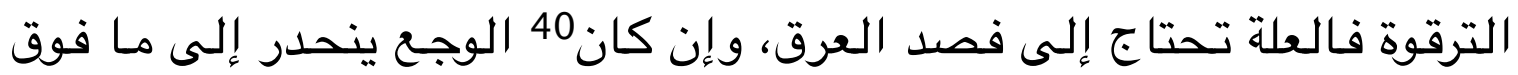

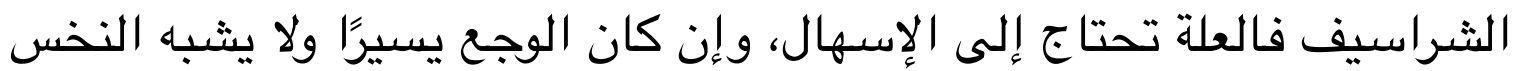

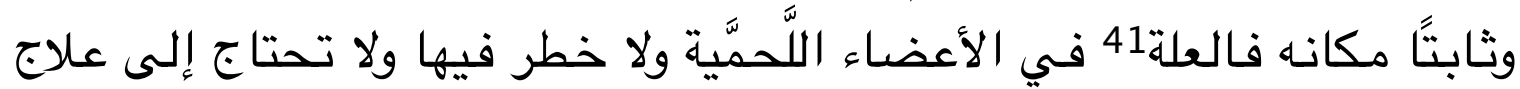

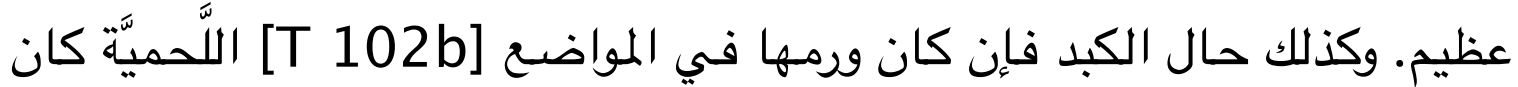

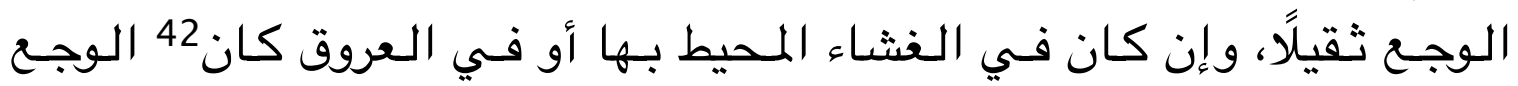
[CB2 91a]

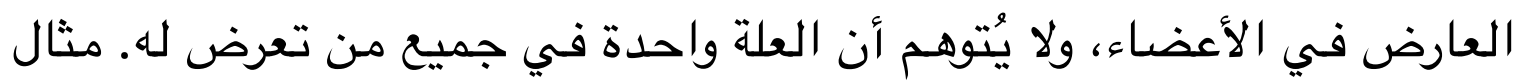

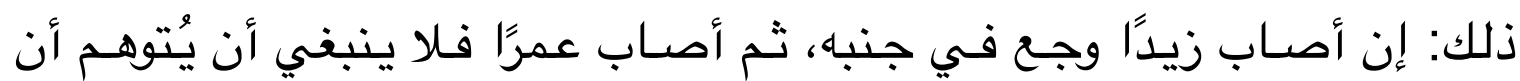

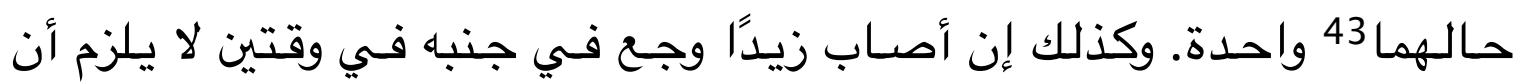

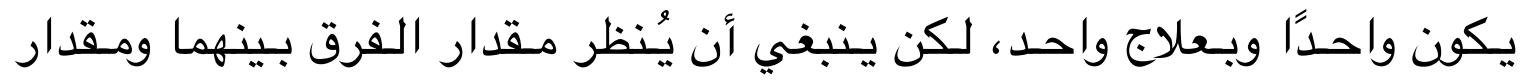

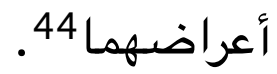

\section{] فصل رقم 269 ]}

قـال أبـقراط: الـعلل الـتـي تكون فـي المـثانــة والـكلى 45 يعسـر برؤهـا46 في المثنسايخ.

MSS.

كانت : 10 KS KSS.

31 ] MSS: om. K1.

كان ] وكان KS1.

] حالها : حالهما T.

اعرضهما K1 K1.

MSS.

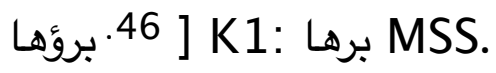


قال عبد اللطيف: إذا حدث في هذه الأعضاء علل عسر برؤهـا 47 لدوام

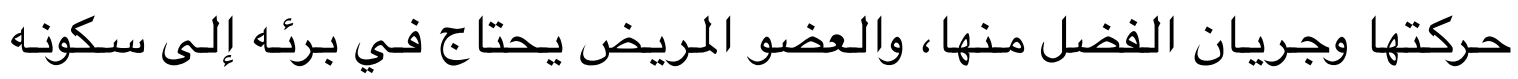

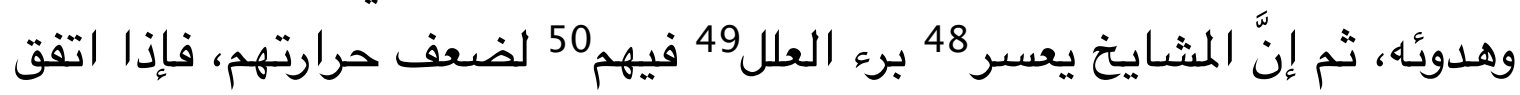

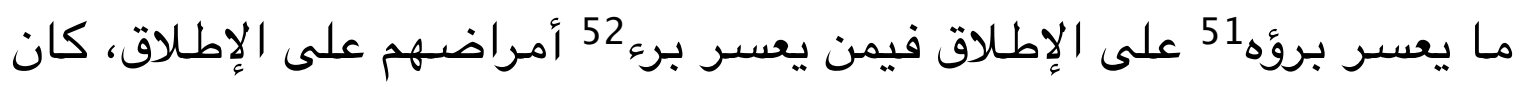
برؤها 53 أثند عسرًا.

\section{]}

قال أبقراط: ما كان من الأوجـاعم5 التي تعرض في البطن أعلىى موضعًا فهو أخف، وما كان منها ليس كذلك، [K1 78b] فهو أشد.

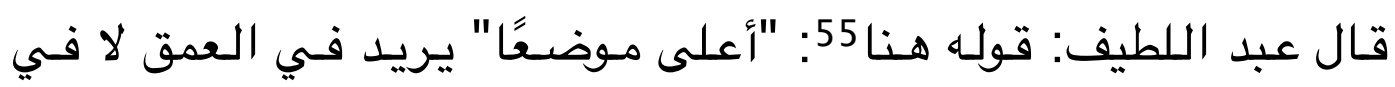

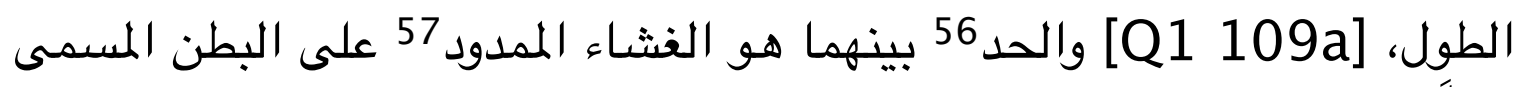

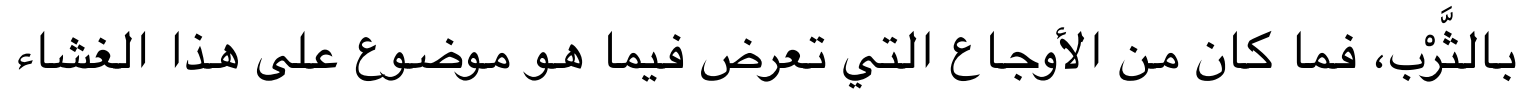

برؤها MSS.

أعسر Q أعسر Q1 MSS.

MSS.

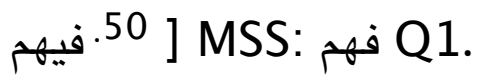

· برؤه Q بره : 51 Q K1, T.

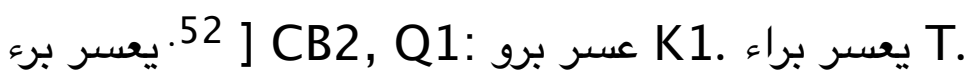

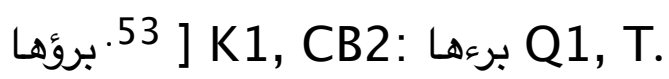

الأواجع : الأوجاع Q

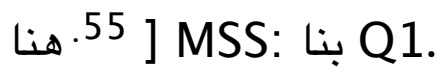

] MSS: والجلد K1. والحد K1.

الممدد : المتمدد R1, الممدود Q1, CB2. 
سماه أعلى موضعًا، وما عرض من وراء هذا الغثاء، أعني في الأمعاء والمعدة

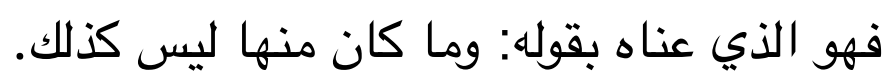

\section{]}

قال أبقراط: ما يعرض من القروح في أبدان أصحاب الاستسقاء،

$$
\text { ليس يسهل برؤه }
$$

قال عبد اللطيف: القروح لا تندمل حتى تجف جفافًا بالغًا، وليس يسهل

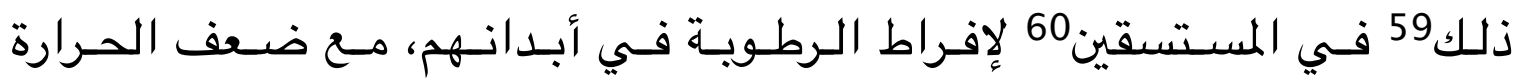

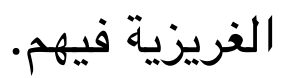

\section{] 272 [صصل رقم]}

قال أبقراط: البثور العراض616 لا يكاد يكون معها حَكَّة.

قال عبد اللطيف: البثور العراض تحدث عن مادة بَلغميَّة ولاكئه يكون معها

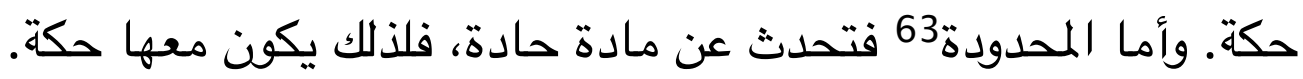

\section{] 273 [صل رقمل}

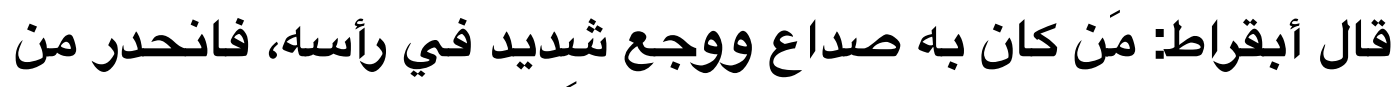

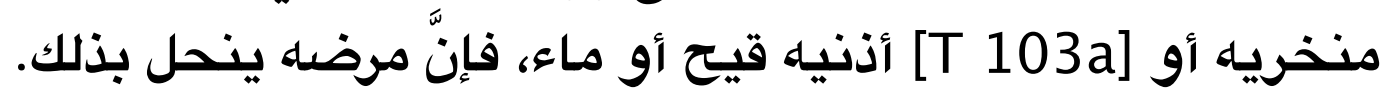

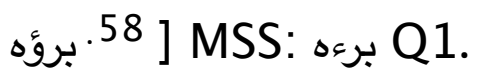

T وذلك : MSS.

المستسقيين K1. المستسقين KS1.

الأغراض Q العراض Q1 MSS.

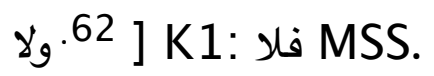

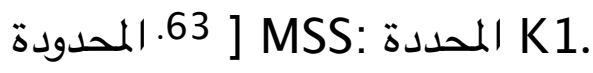


قال عبد اللطيف: إن كان مـا يُسـتهرغ مـن المنخريـن والأذنين هـو مـادة الصداع والوجـع، كان ذلك برؤه وانقضى بـه مـرضسه، و إلا فـلا. [CB2 91b] مثاله: إذا 64 حدث في الرأس وجع من قِبل ورم دموي أو من كثرة رطويات غير ونات

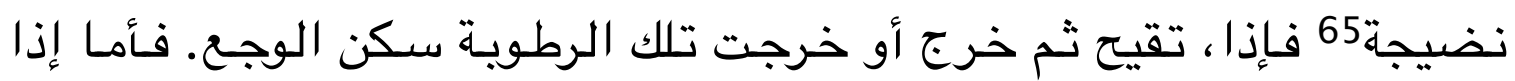

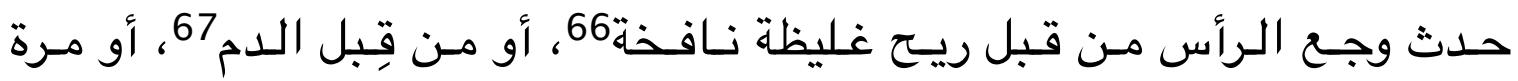
صفراء68 تلذع الرأس، فبرؤ69 العلة يكون بأثنياء أخرى.

\section{]}

قال أبقراط: أصحاب الوسواس السوداوي، وأصحساب البرسـام، إذا حدثت بهم البواسير، كان ذلك فيهم دليلاً محمودًا.

قـال عبد اللطيف: الـوسـواس السوداوي هـو اخـتلاط الـذِّهـن عـن مِرَّة

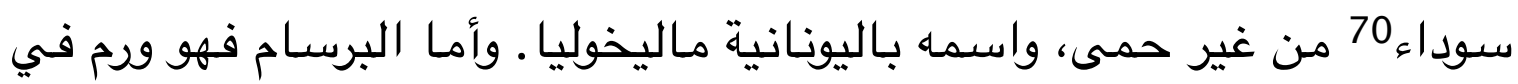

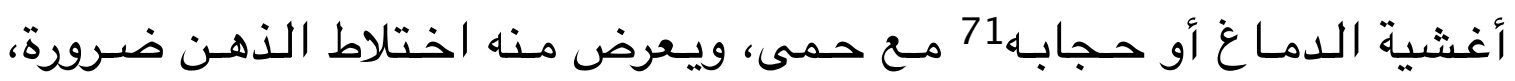
ويسمى باليونانية فرانييطس 72. وأما البواسير [Q1 109b] فيعني بها انفتاح

إ K1.

] K1, T: نضجة Q1, CB2.

] MSS: الريح الغليظة النافخة T.

T.

الصفراء : Q1, CB2. بالصفراء T.

MSS. 69 K1: فبرء 69 فبرؤ

MSS.

وحجامه : و K1 MSS.

فرنيطس : فرنييطس C1. فرانييطس CB2. فرنسط T2 
أفواه عروق المقعدة، وخروج هـا الدم، وهـو الأسـود العَكِر 73، هو استقراغ مـادة

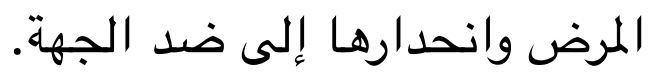

\section{]}

قال أبقراط74: من عوله من بواسير مزمنة حتى يبرأ75، ثم لـ

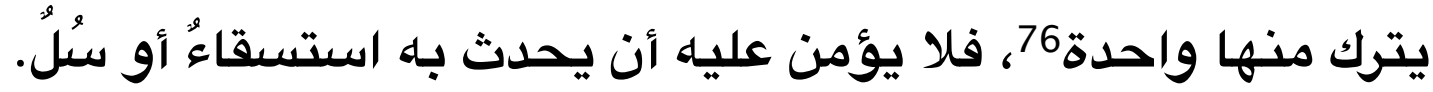

قال عبد اللطيف77: ليس يمكن أن يحدث بواسير دون انفتاح أفواه عروق

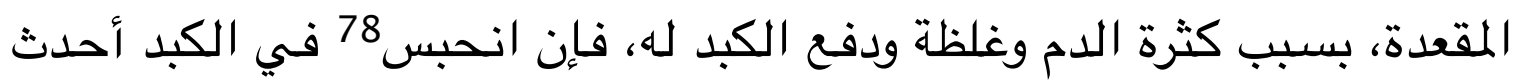

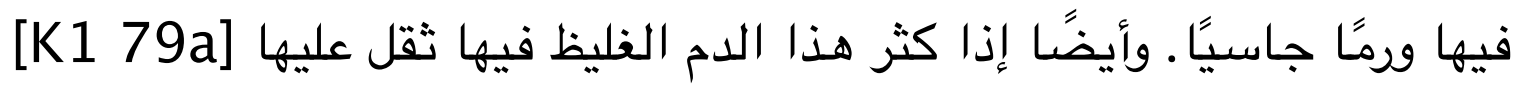

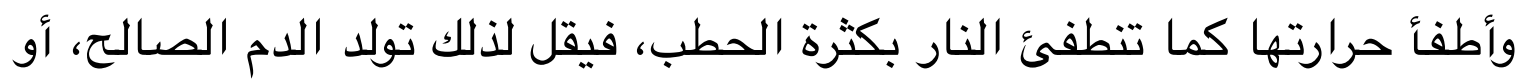

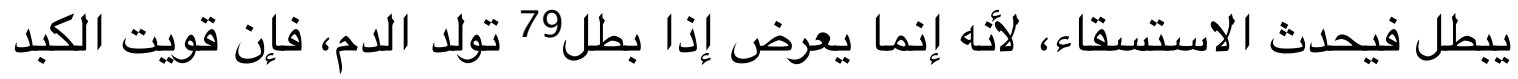

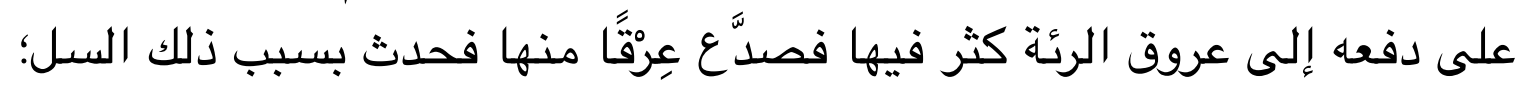
فلذلك أمر أبقراط أن يترك من البواسير واحدة ليستفرغ بها ما يتولد في الكبد من عكر الدم \#ولاسيما إن كانت العادة للطبيعة أن تستقرغ منها عكر الدمامعن 80 منذ [T 103b] زمان طويل.

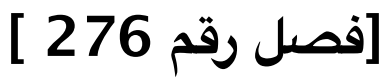

العسكر : العكر Q1, CB2, CB2.

.

7. برأ : T.

J واحدا : واحدة K1.

[ MSS: om. T.

الحبس T.

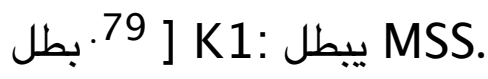

] ولا سيما إن كانت العادة للطبيعة أن تستفرغ منها عكر الدم 
قـال أبـراط: إذا اعترى إنسـانًا فـواق، فحدث بـه عطاس، سـكن

قال عبد اللطيف: العطاس إنما يبرئ الفواق الكائن مـن الامتلاء، لأنـه

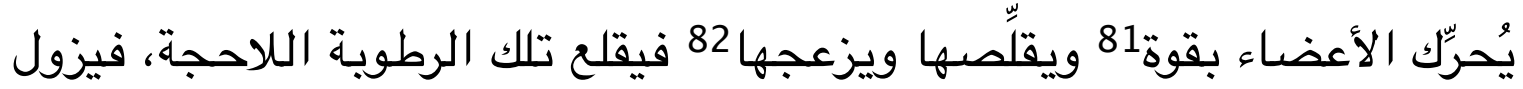
الفواق. فـأما 83 الفواق الكائن عن الاستفراغ فليس يبرئه العطاس، وهـو مـح ذلك ولك نادر الوقوع بُعيد 84 البرء.

\section{]}

قال أبقراط: إذا كان بإنسان استسقاء فجرى الماء منه في CB2] [92a عروقه إلى بطنه، كان بذلك انقضاء مرضه.

قـال عبد اللطيف: هـذا أحـد المـثالات [Q] 110a] فـي الاسـتقراع85 الكائن من تلقاء نفسـ، لا بدواء مُسبهِل ولا بغيره.

]

قال أبقراط: إذا كان بـإنسان اختلافُّ قد طال، فحدث بـه قيء من تلقاء نفسه، انقطع بذلك اختلافه.

قال عبد اللطيف: هـا مثال آخر في الاستفراغ الكائن من تلقاء نفسها،

ويجذب المعدة ] add.

] ونزعجها : ويزعجها K1.

] وأما : وأما K1.

84 ] MSS: بعيد K1.

[ K K1: استفراغ الاستفراغ MSS. 
وإيـاه يـبغني أن يمتثل86 الطبيب ويـه يقتدي، والمـنفعة فـي هـا وشـبهه 87 إنـما تكون بطريق الجذب إلى الجهة المضادة.

\section{]}

قال أبقراط: من اعتراه وجـع ذات الجنب أو ذات الرئـة فحدث بـه

اختلاف، فذلك منه دليل سوء.

قال عبداللطيف: قولـه: "مـن اعتراه" أي مـن استولت عليه هـذه العلل وأتخنته ودامت به، ومعلوم أنه ليس يشارك العضو العضو في علته إلا إذا كانت شديدة متفاقمة. قوله: "فحدث به اختلاف" أي تفاقمت هذه العلل حتى استضرت

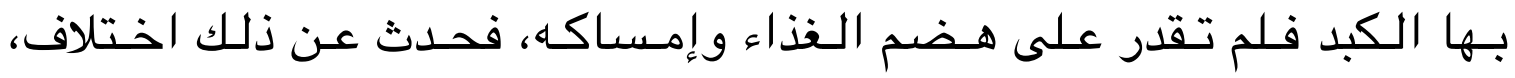

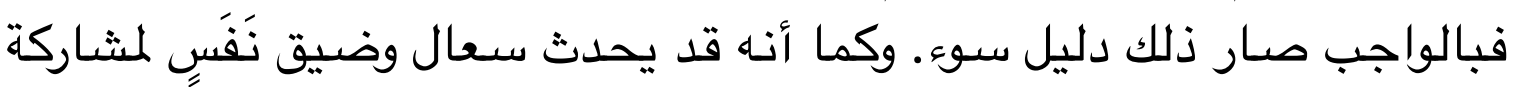

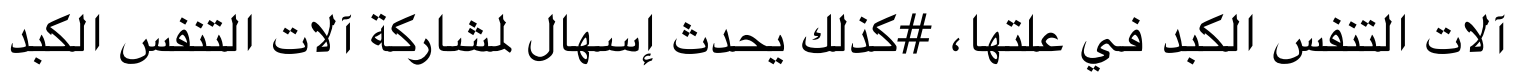

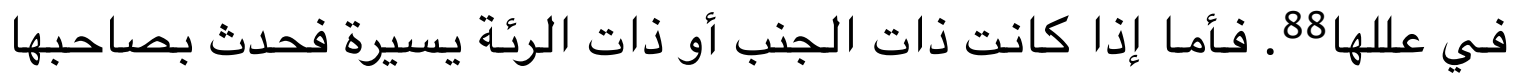

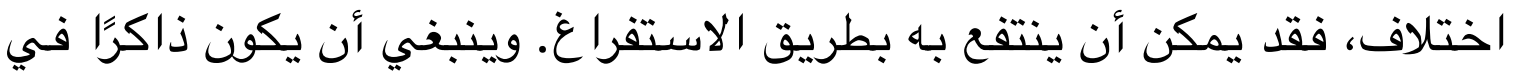

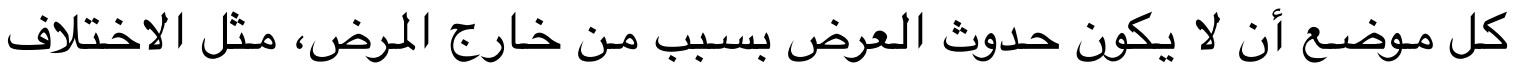

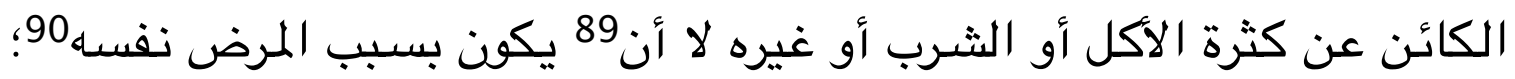

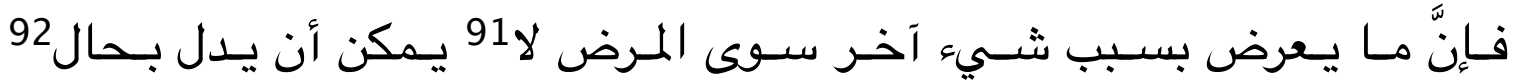

] يمثل : 86 ] يمتثل CB2.

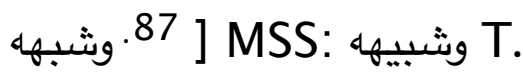
] MSS: om. T.

إلا أن : MSS.

] بنفسـ T.

ل.91 ] add. يدل أنه Q1.

92 ] MSS: تجال CB2. 
المرض، إذ93 كان يجب أن يكون الدليل متصلًا بالشيء الذي [T 104a] يدل عليه.

\section{] فصل رقم 280]}

قال أبقراط: إذا كان بإنسان رمدُ فاعتراه اختلاف، فذلك محمود.

[K1 79b]

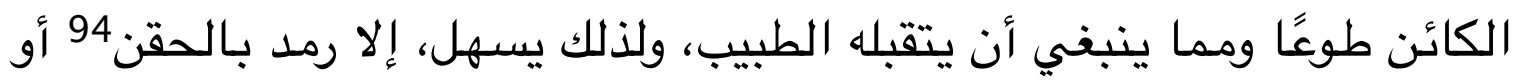

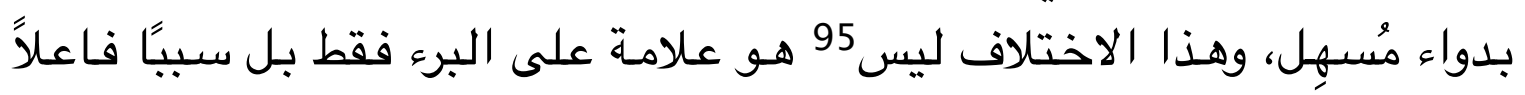
للصحة.

\section{] 281 [صل رقم]}

قـال أبـقراط: إذا حدث فـي المـثانـة خَرْق، أو فـي الـدمـاغ، أو فـي

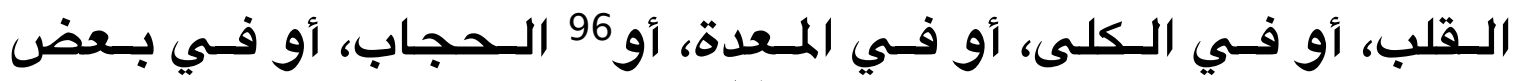
الأمعاء الدقاق، أو في الكبد، فذلك قَتَّال.

قال عبد اللطيف: [Q1 110b] بعض هذه الأعضاء إذا حدث فيها خرق

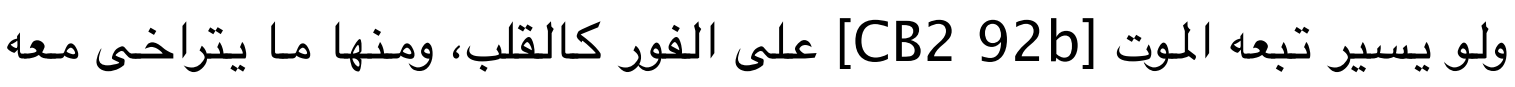

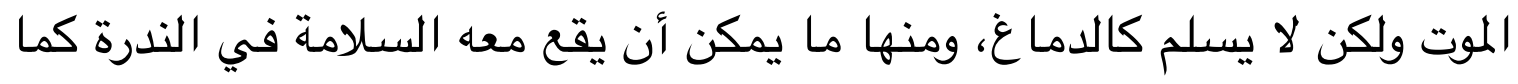

إذ

] MSS: بالجفن K1.

] MSS: om. K1.

في 36 add. في T. 


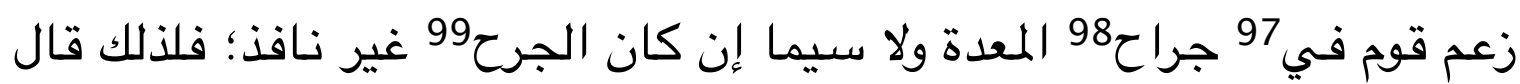

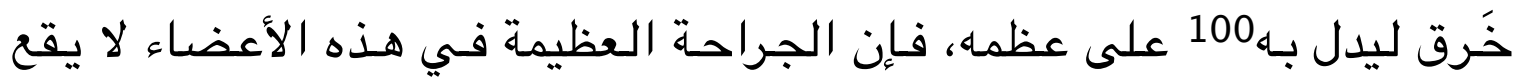

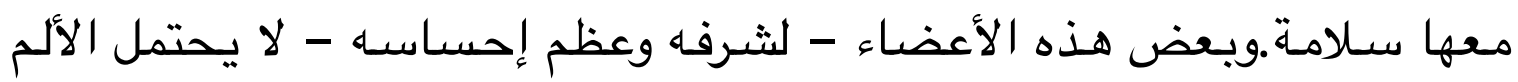

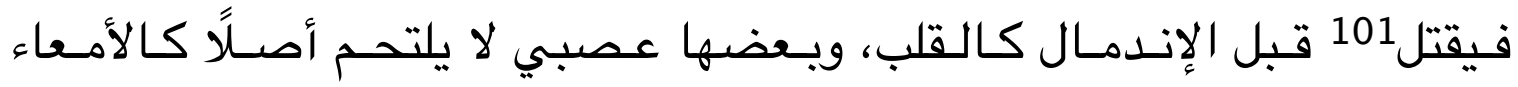
والمثانة.

فأما الكبد فإذا وقع بها جراحة غائرة في بعض زوائدها، فقد تبرأ، بل قد

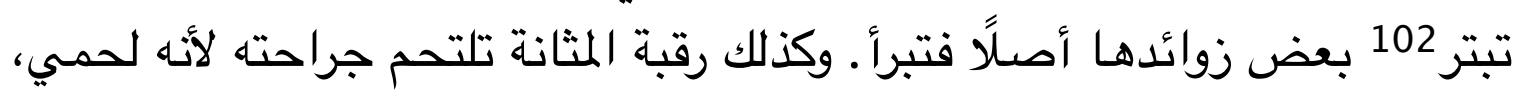
وأما الكبد نفسها إذا عرض في جرمها جراحة غائرة انفجر الدم وكان الموت قبل

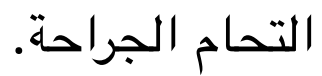

وأمـا الدما غ فقد يقع به جراحة عظيمة غائرة

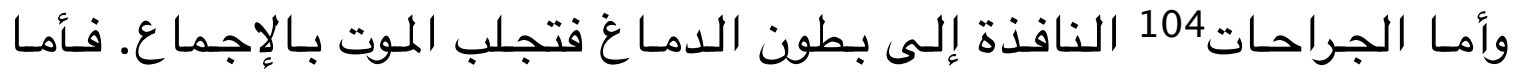

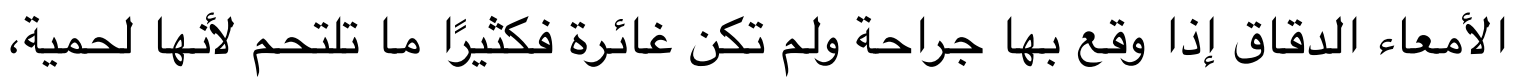

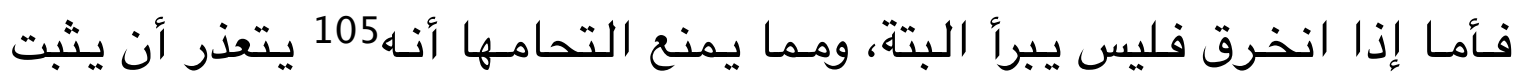

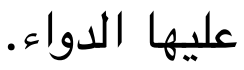

جراحة في Q 97 add.

خراج K1. خراج : خراج C CB2, Q1.

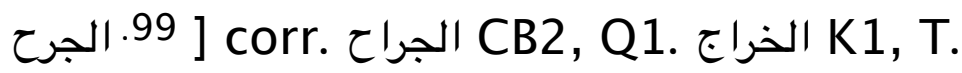

100 ] MSS: أنه K1.

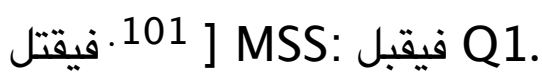

102 ] MSS: تبرء Q1.

103 ] MSS: om. T.

الجرحات K1. الجراحات MSS.

105 ] MSS: أنه Q1. 


\section{]}

قال أبقراط: متى انقطع عظم أو غضروف أو عصبة أو الموضع

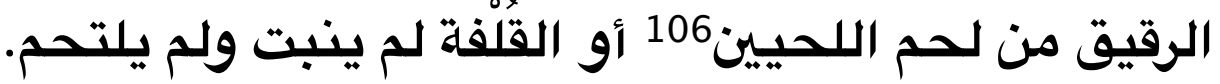

قال عبد اللطيف: الأعضاء الأصلية الكائنة من النطفة إذا ذهبت أو ذهب

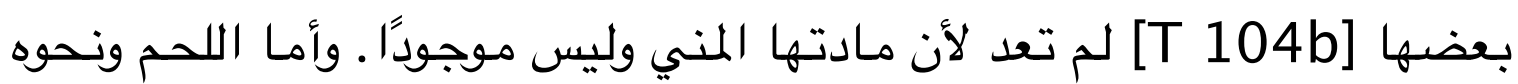

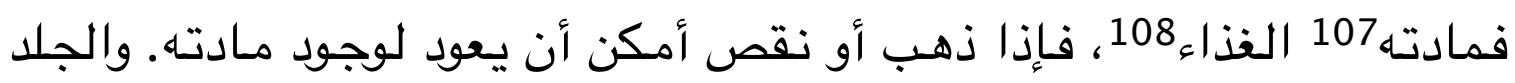

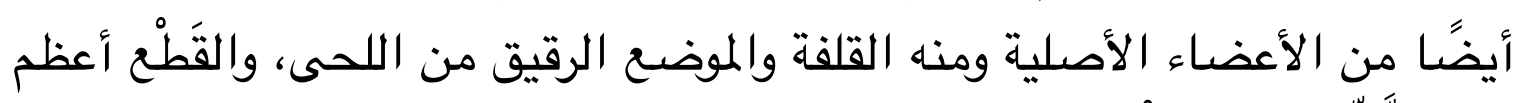

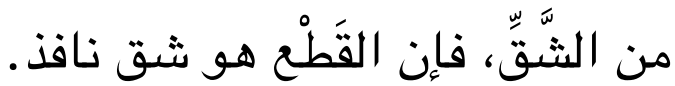

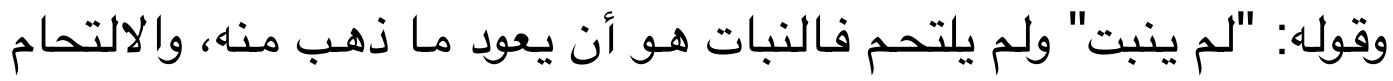

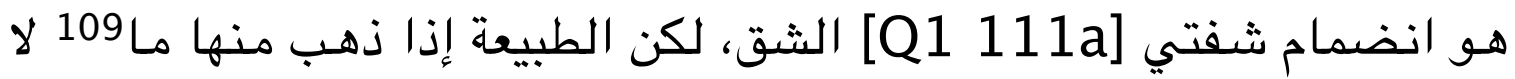

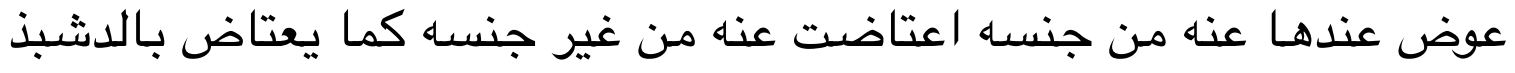

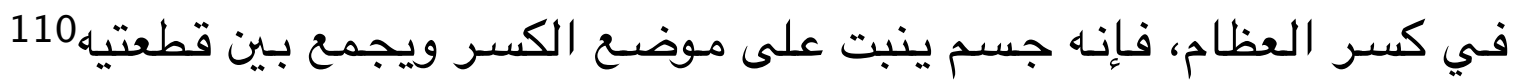

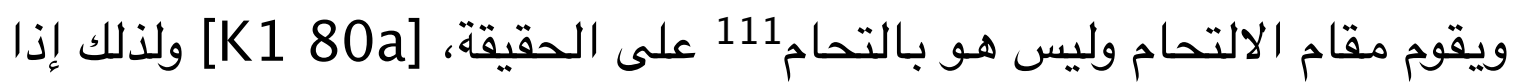
نزع الدشبذ وجد الفصل بيّنًا ظاهرًا.

\section{]}

الحنين K1.

فمادية : فمادته Q107 MSS.

K1. للغذاء K1.

L.109 ] MSS: om. K1.

Tطيعته : قطعتيه T.

111 ] MSS: om. K1. 
قال أبقراط: إذا انصب دمُ إلـى112 فضساء الـصدر113 على خـلاف الأمر الطبيعي، فلا بد من أن [CB2 93a] يتقيَّح.

قال عبد اللطيف: المـكان الطبيعي للام هـو العروق والكبد والقلب لأنـه الموضع الذي ينحفظ114 عليه فيه قوامه وطبيعته فلا يفسد لأن فيه كونه وحفظه، فإذا خرج عن مكانه الذي فيه يتكون وينحفظ إلى مكان غيره لم يمكن أن يبقى لمانه

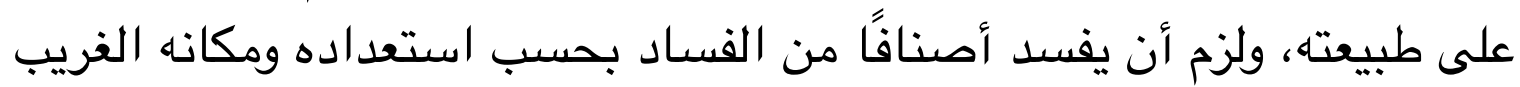

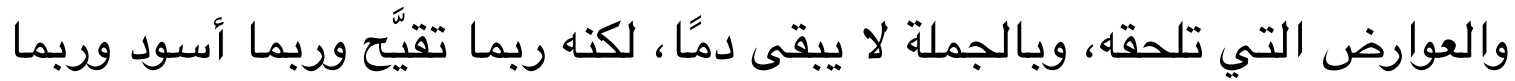

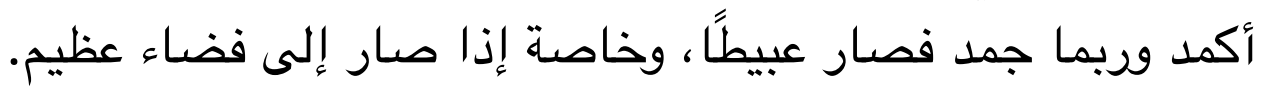

فقوله: "فـلابـ115 مـن أن \#يـقيح" هــا أحس أنـواع فسـاده، ولهـذا كتب

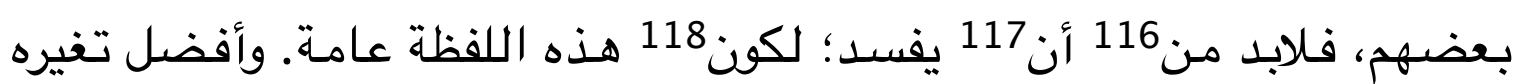

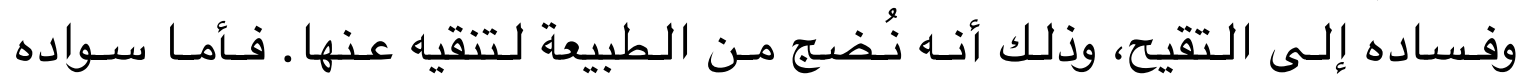
واكمداده ونتنه فيكون من طبيعته إذا لم تحسن الطبيعة تدبيره كما يجري عليه

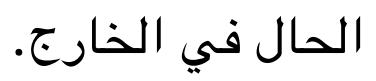

\section{]}

\section{قـال أبـقراط: مـن أصسابه جـنون فحـدث بـه اتسـاع الـعروق الـتي}

على : ع 112 KSS.

113. الصدر ] MSS: om. K1.

يحفظ T. 114 ] MSS.

115 ] فلابد K1, T: om. Q1, CB2.

116 ] K1, T: om. Q1, CB2.

117 ] MSS: om. T. ] K1: ليكون MSS. 
تعرف بالدوالي أو البواسير119، إنحلّ عنه جنونه.

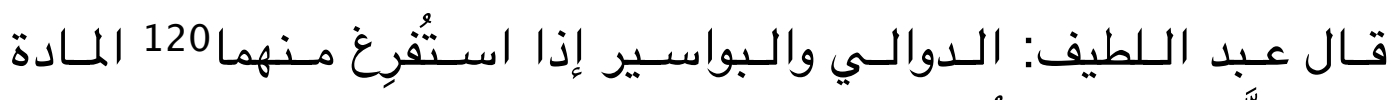

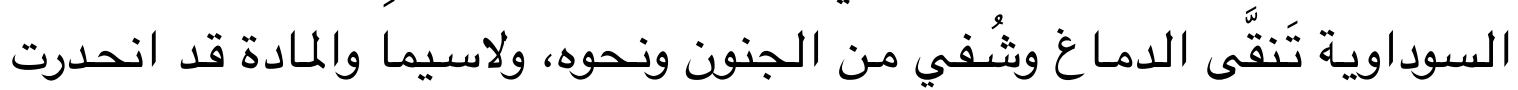

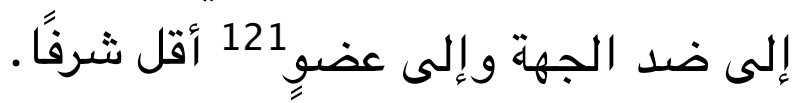

\section{[ فصل رقم 285]}

[T 105a] المرفقين، يحلها فصد العِّقُ.

قال عبد اللطيف: إذا كانت122 الأوجاع تنتقل فالفاعل لها خلط يجري123 وينتقل [Q ذللك الخلط من باطن المرفق بالفصد إذا 124 كنا نراه يجري إلى تلك الناحية، كما

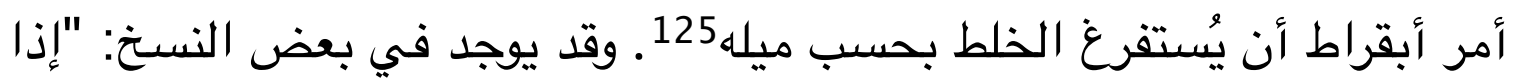

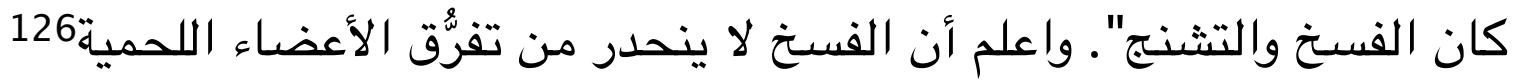
من العضلة127، وإنما يريد إذا كانت أوجاعه تنحدر، فاستفرغ مان التها انصب إليه

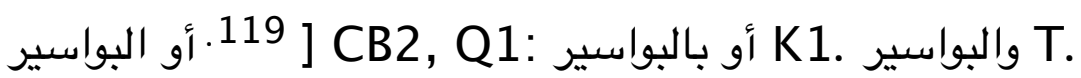

بهما : بهS.

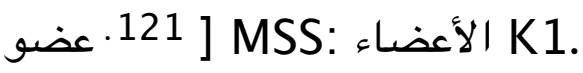

كان : 122 KS KSS.

Tويجري : ويجري ] MSS.

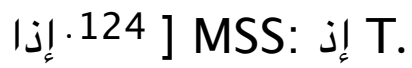

125 ] MSS: ميله K1.

للحمية : ل1261. اللحمية MSS.

الفضلة: العضلة I27 MSS العضلة CB2. 
بفصد المرفق.

\section{] فصل رقم 286]}

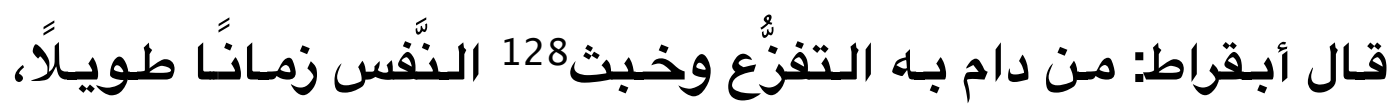
فعلته سوداوية.

قال عبد اللطيف: إذا دام ذلك زمانا ولم يكن له سبب بادٍ فبيِّنٌ أنه وسواس

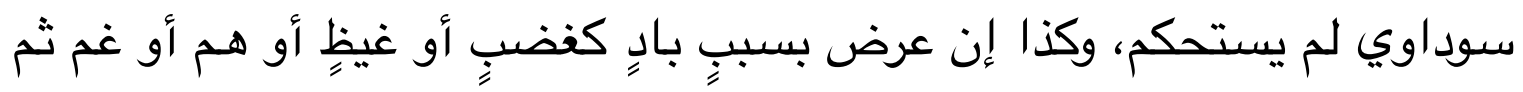

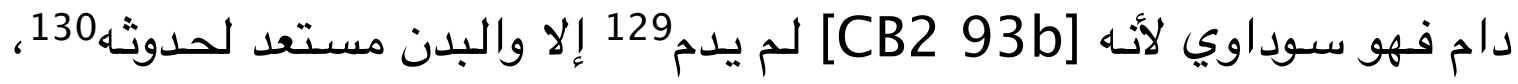

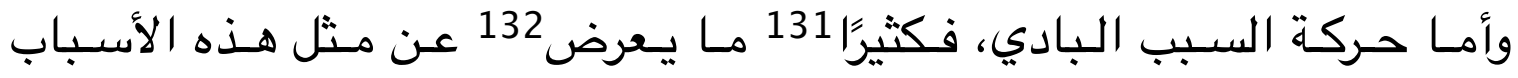
الجنون بالحقيقة إذا صادفت استعدادًا 133.

\section{]}

قال أبقراط: متى انقطع بعض الأمعاء الدقائق لـ134 يلتحم.

قال عبد اللطيف: [K1 80b] هــا الفصل قـد سبق فـي جملة فــل سـابق، فليس لإعادته جدوى، وأظن أبقراط كان إذا صـح عنده فصل بالتجربـة أثبته و إن 135 كان فيه تلاعرير.

128 128 MSS: وخبث T.

129 ] يدم يلزم K1.

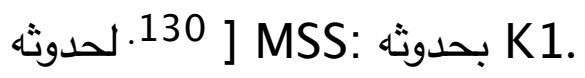

131 ] فكثيرًا فكثير : ف1, T1, CB2.

132 ] add. ماعرض K1.

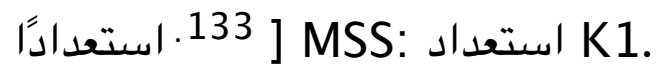

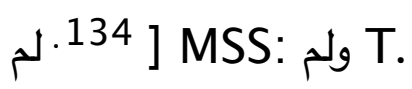

135. و إن ] MSS: om. K1. 


\section{]}

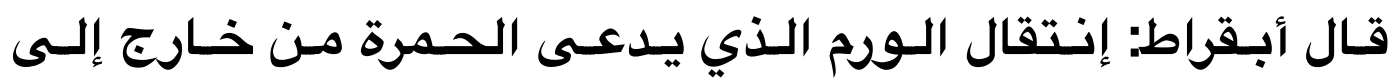

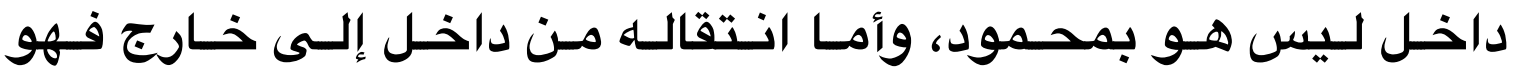

قال عبد اللطيف: كل ورم بل كل علة تنتقل من داخل إلى سطح الجلد

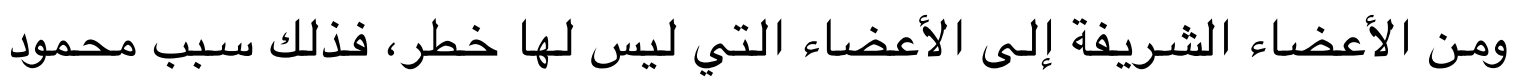

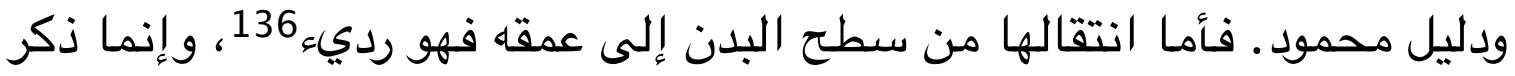

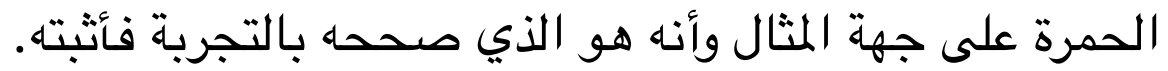

\section{]}

قال أبقراط: من عرضت له في الحمى المحرقة رعشدة، فإن اختلاط ذهنه يحلها عنه.

قال عبد اللطيف: الرعشة في الحمى المحرقة تدل على انتقال المادة من العروق إلى العصب، فإذا كثرت وتمكنت 137 انتقلت [T 105b- Q1 112a]

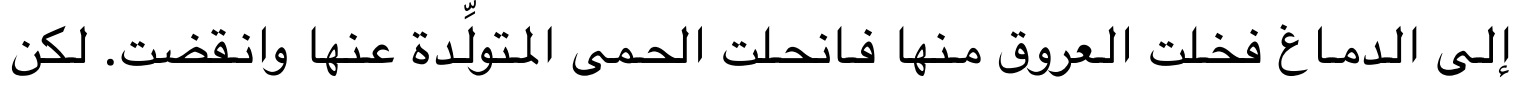
جالينوس ينكر هذا الفصل بسبب أن عادة أبقراط إنما يستعمل قوله يحلها إذا إلـا

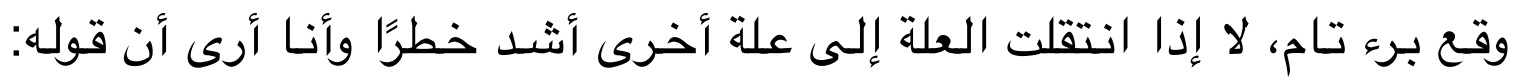

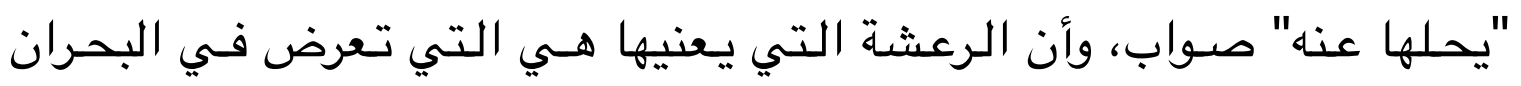

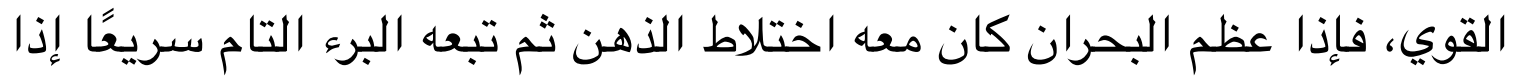

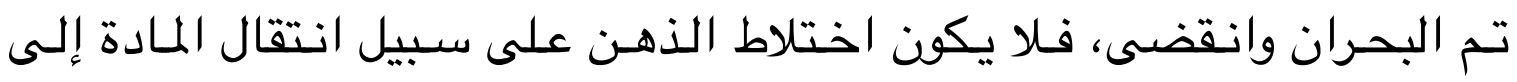

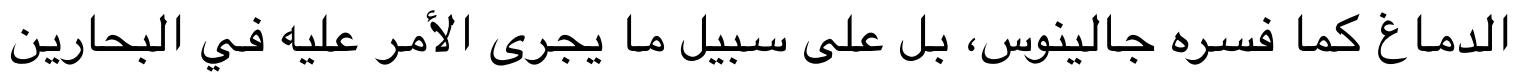

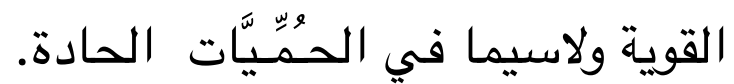

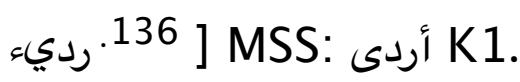

ويمكنت Q وتمكنت Q137 MSS. 


\section{]}

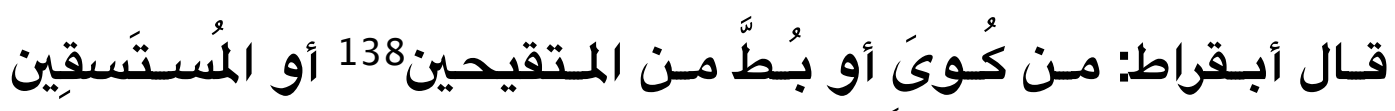

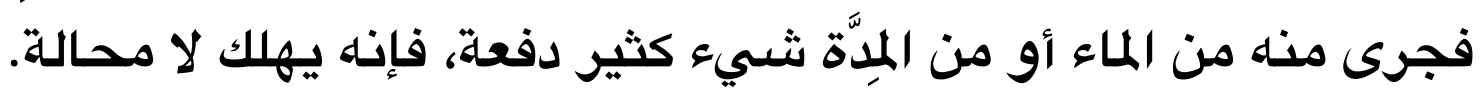

قال عبد اللطيف: المتقيح في عرف أبقراط هو الذي تولَّدت فيه المِّدَّة 139

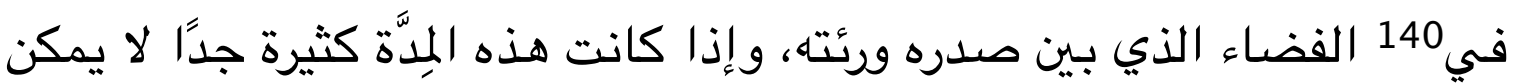

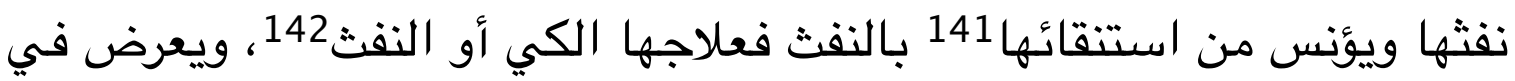

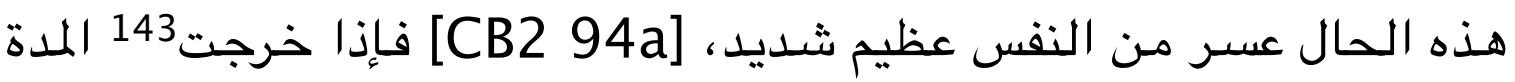

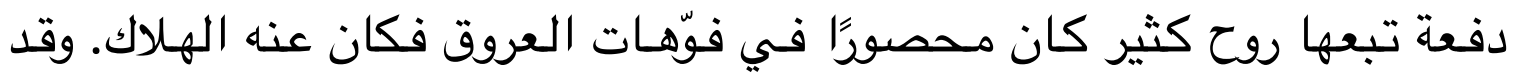

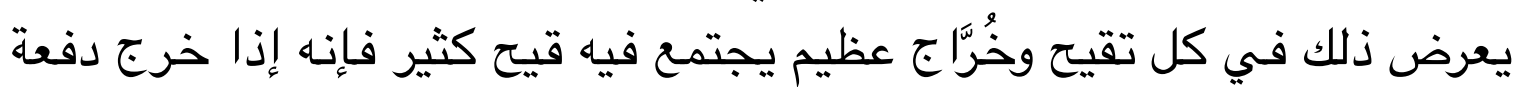

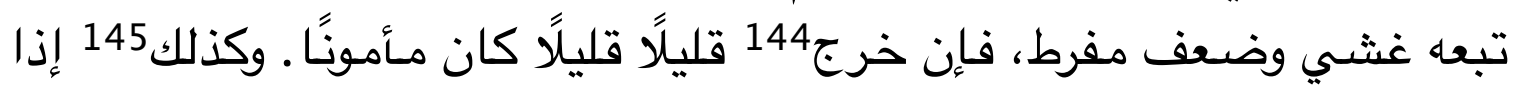
بزل146 ماء المستسقى147 دفعة كان هلاكه سريعًا لهذا السبب، وأيضًا لأن 148

المنفحين: المين CB2.

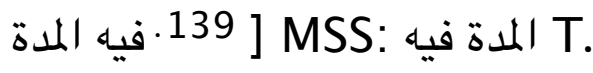

140 ] MSS: om. T.

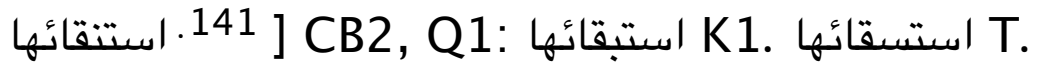

النق : 142 النفث R1, CB2. ill. T.

أخرجت : أخرجت K143.

فإِ أخرج : فإذا خرج C1, K1. 144. فإن خرج CB2.

K1.

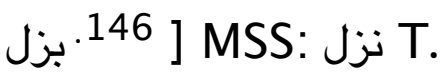

K1.

أن K1 أن KS1. 
الكبد فيها ورم جاس 149 فما دام الماء في البطن فهو يحمل ثقل الورم، فـإذا

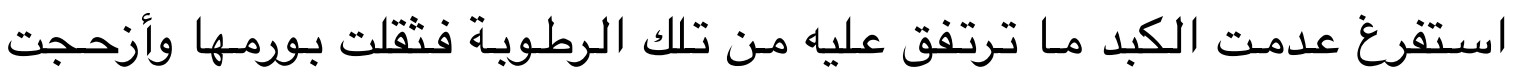
وجذبت معها الحجاب وما في الصدر [K1 81a] من الأحشاء إلى أسفل.

\section{]}

\section{تال أبقراط: الخِصيان لا يعرض لهمب150 النَّقرَسُ ولا الصَّلَحُ.}

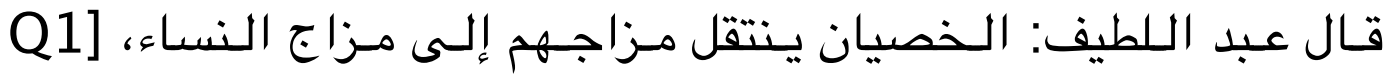

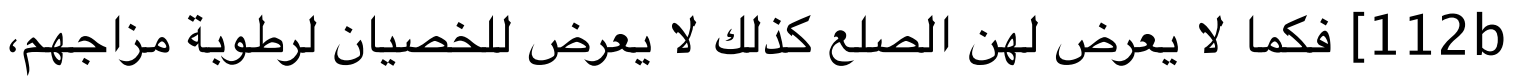

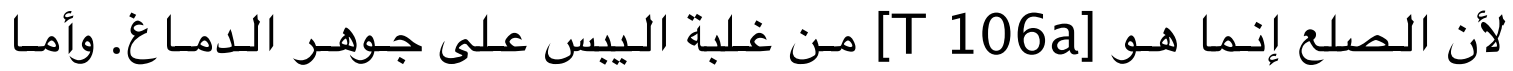

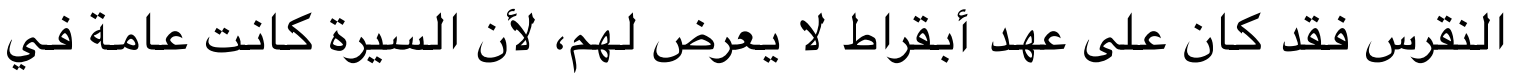

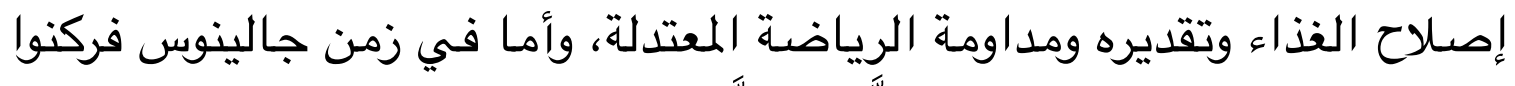

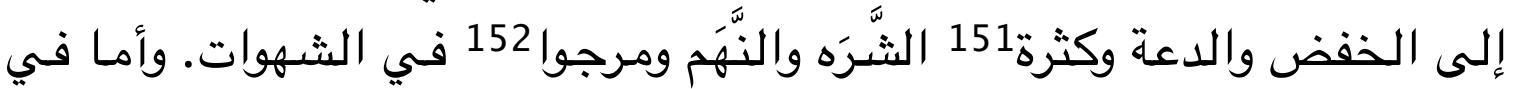

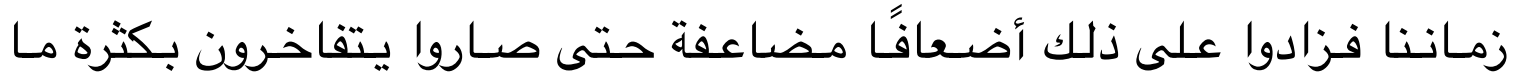

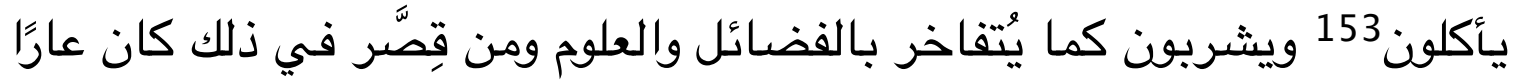

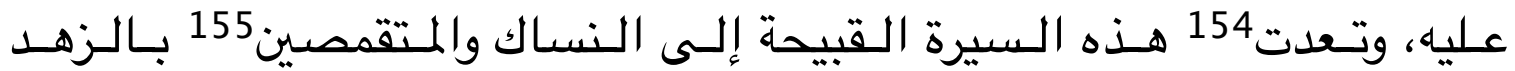

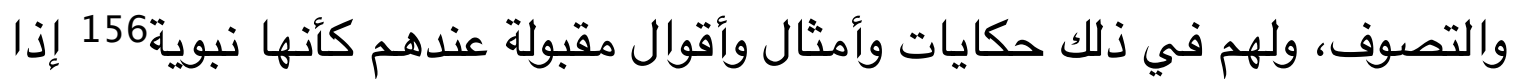

جاسي :CB2, T.

لهما T. 150 ] MSS:

فكثرة : فكثرة K1.

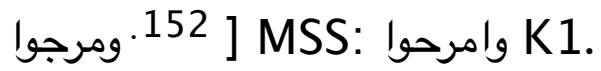

153 ] MSS: يأكلون K1.

154 ] Mتعدت T. وبعدت T.

والمنقمصين : والمتنقمصين Q1

156 ] K1, T: يوية Qن ينويه C1. ينهويه CB2. 
قيلت157 للإنسان ألزمته158 بأكل كل مـا يجد، مثل قولهم: الصوفي يـأكل على

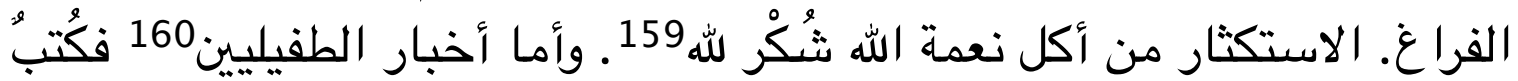

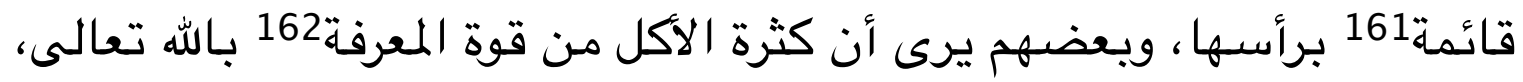

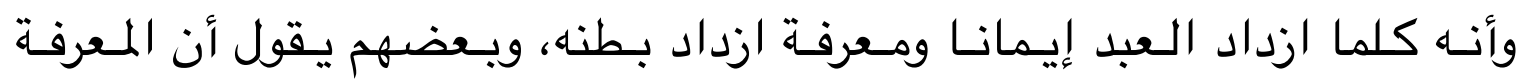

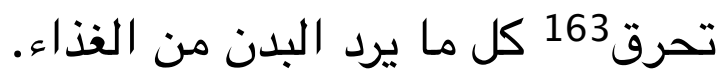

واعلم أن ضعف القدمـين الطبيعي لازم لأصـحاب النقرس، ولذلك تتجذب في نقاب

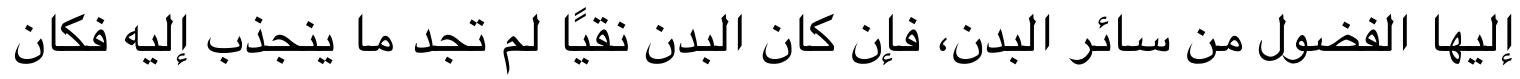

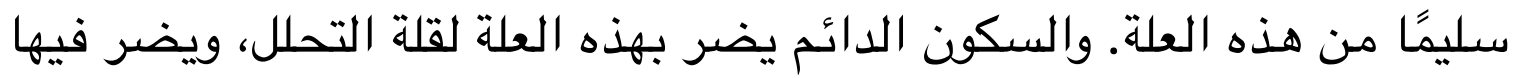

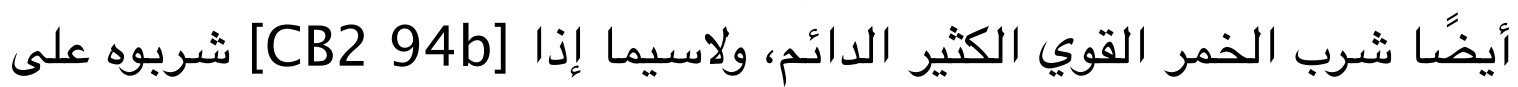
جوع، لعظم164 نكايتها 165 بالعصب؛ ويضرهـم أيضًا الجماع ولاسيما من أكرا أكره نفسه عليه وأفرط فيه.

قال جالينوس: وقد كان مـن يصيبه النقرس على عهد أبقراط قليلًا جدًا

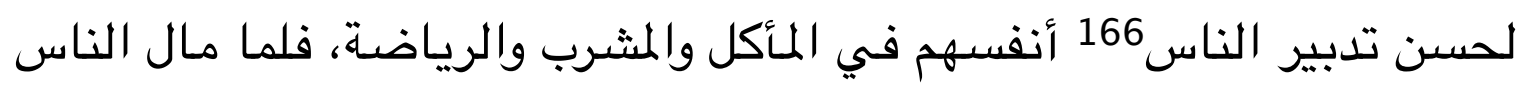

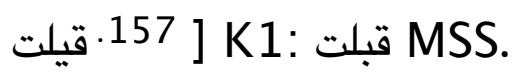

الزمنه : ألزمته Q158 ] MSS.

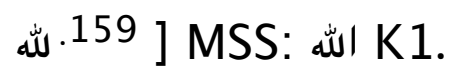

] K1, Q1: أخيار الطفيلين T. أخبار الطفيلين CB2.

161 ] MSS: ثابئمة K1.

المعروفة T T. المعرفة T.

] 163 ت تحرق MSS: تخرق CB2.

164 ] لعظم CB2.

] نكايته : نكايتها T.

الباس الناس CB2. 
إلى الدعة وانهمكوا في الشهوات وأكثروا في ذلك بحيث 167 لا يمكن أن يتوهـ

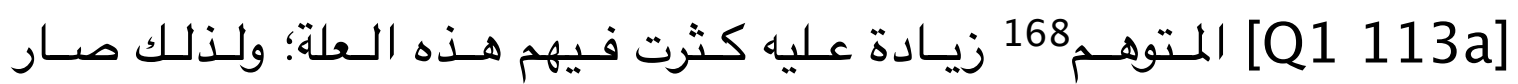
الخصيان يبتلون169 في هذا الزمان بهذه العلة. [T 106b] قال جالينوس:

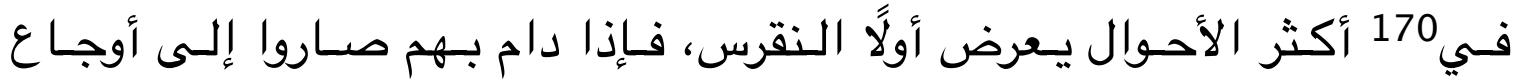

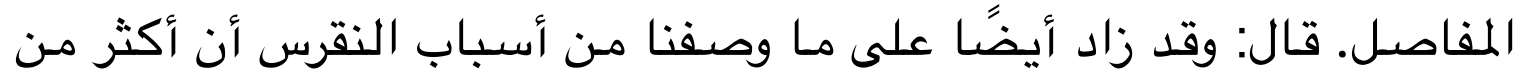

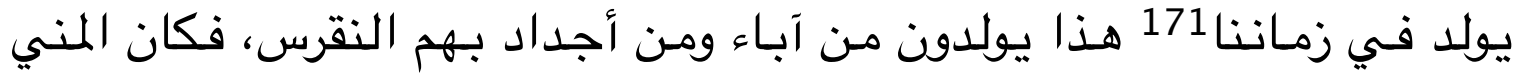

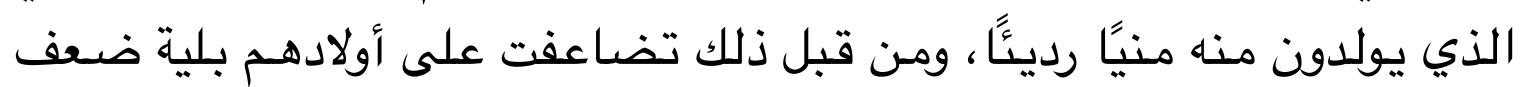
القدمين172، وزاد على ما كان عليه في آبائهم.

وهذه [K1 81b] العلة إنما تكون لدفح الأعضاء العليا الثـريفة إلى دأى

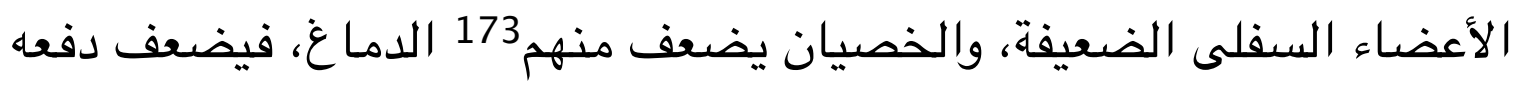

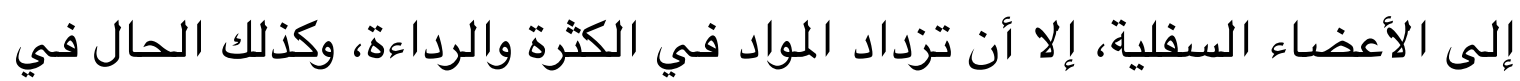
النساء والصِّبْيَان.

\section{]}

\section{قال أبقراط: المرأة لا يصيبها النَّرَسَ، إلا أن ينقطع طمثها.}

قال عبد اللطيف: الطمث174 يَستفرغ من أبدان النساء الفضول الرديئة

167 ] بحيث T. بحبيه T.

[168 ] المتوهم 168 MS: om. T.

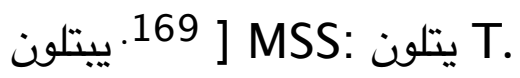

170 ] MSS: om. T.

زمنتا : 171 ] زمانتا MSS.

المتقدمين: القدمين K172 ] MSS.

173 ] K1: فيهم MSS.

بالطمث T. بالطمث T. 
فتأمن لذلك هذه العلة، فإذا انقطع طمثها كانت معرضة لها، وهذا أيضًا كان في

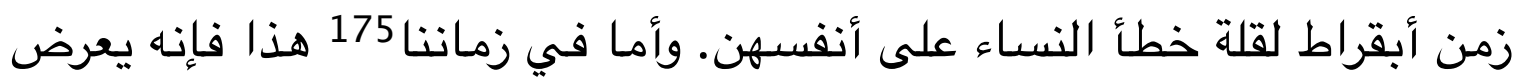

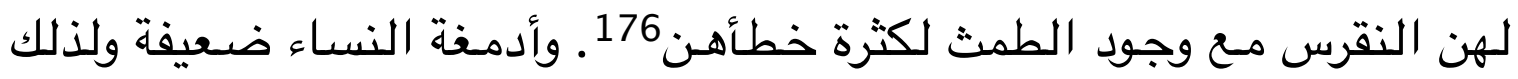
تضعف عقولهن، والأعضاء السفلية منهن كبار، أكبر من الأعالي، بخلاف الحال

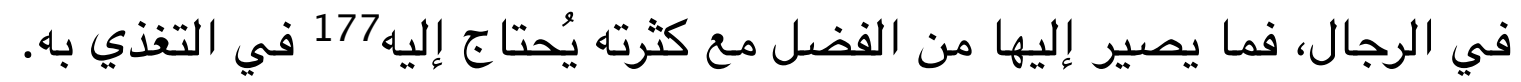

\section{]}

قال أبقراط: الغلام لا يصيبه النقرس قبل أن يبتدى في مباضعة الجماع.

قال عبد اللطيف: الجماع مما يعين في تولّّد هذه العلة، وأيضًا فإن الغلام تنصرف المواد في نشئه178، فإذا ابتدأ في البضاع واستغنت أعضاؤه عن أكثر

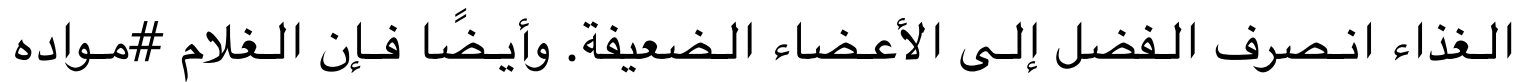
منصرفة نحو العلو فإذا ابتدأ في البذاع أخذت المادة تنصرف إلى أسفل 179 حيث يتكون المني، [Q1 113b] فما رَدوَُ منه مال إلى العضو الضعيف فسقم.

\section{]}

تـال أبـقراط: وجـع الـعينين يحلـ180 شـرب الثَّـراب [CB2 95a] الصرف، أو الحمَّام، أو التكميد، أو فهد العِرق، أو شعرب الدواء.

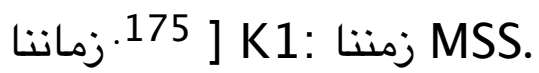

خطنهن : MSS.

.177 ] MSS: om. K1.

178 ] Q1, T: نثئه CB2. نشيئه K1.

[ 179. مواده منصرفة نحو العلو فإذا ابتدأ في البضاع أخذت المادة تتصرف إلى أسفل MSS: om. K1.

180 ] corr. يحلهما MSS. 
قال عبد اللطيف: قال جالينوس: أرى أن أبقراط إنما عرف [T 107a] هذه الأشياء التي ذكرها في هذا 181 الفصل بالتجربة لا بالقياس، ولم يسلك هنا

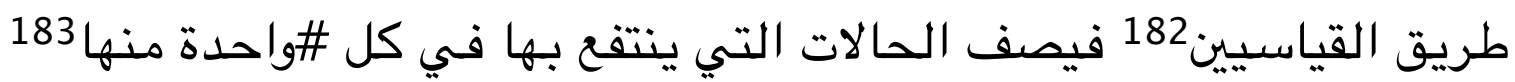

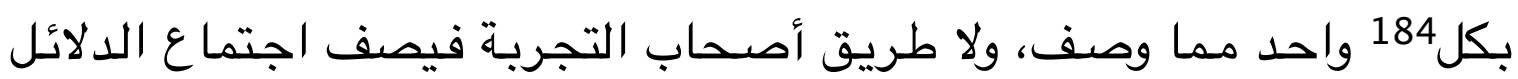

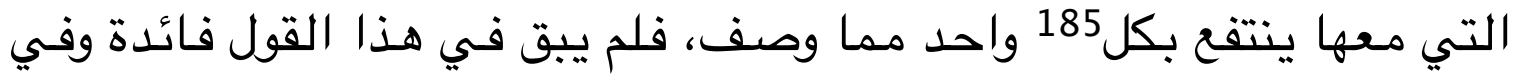

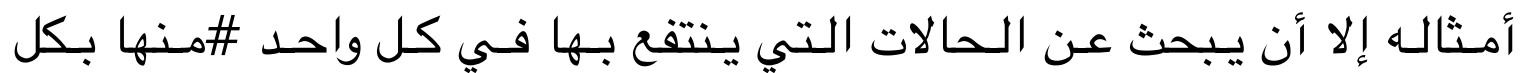

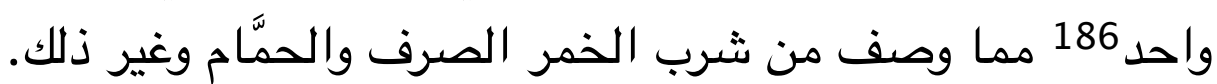

وأنـا أرى أن أبقراط قد أحسن في هذا الفصل غاية الإحسان وأتى 187

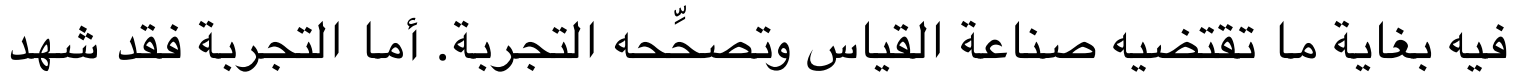

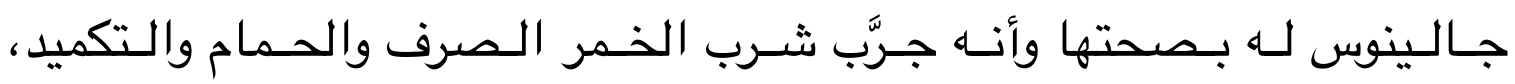

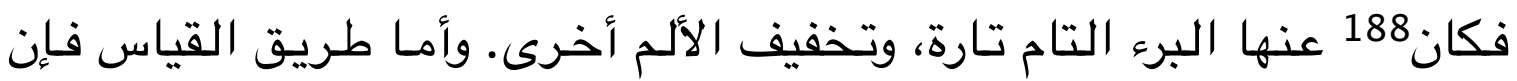

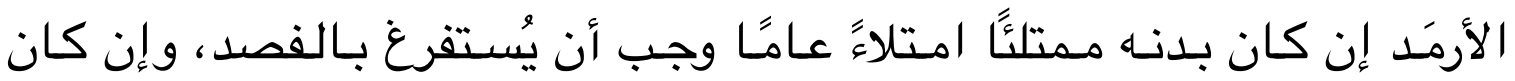

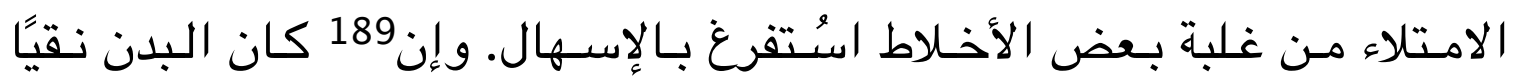

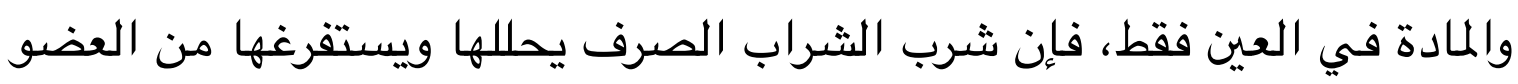

181 ] MSS: om. K1.

الفياسين : الفياسيين Q1, T. T.

183 ] K1, T: om. Q1, CB2.

184 ] MSS: om. T.

185. بكل 185 K1, T: Q1, CB2.

186 ] MSS: om. K1.

والتي : وأتى Q 187 MSS.

وكان K188 وكان MSS.

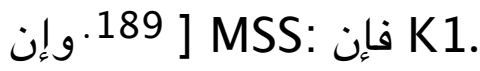




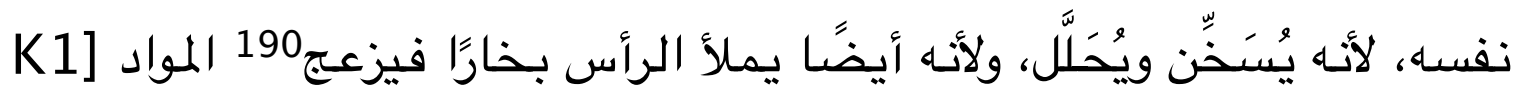
[82a

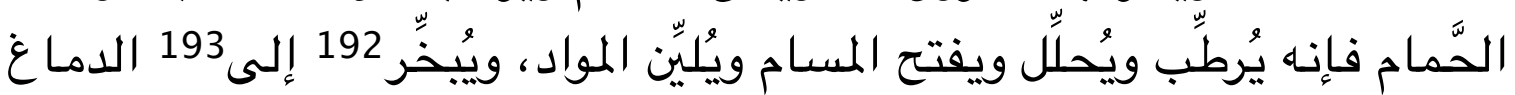

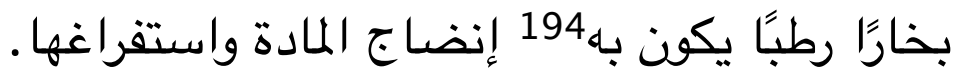

وأما التكميد فهو استقراغ خاص 195 بالعضو وكأنه حمَّام لعضو واحد،

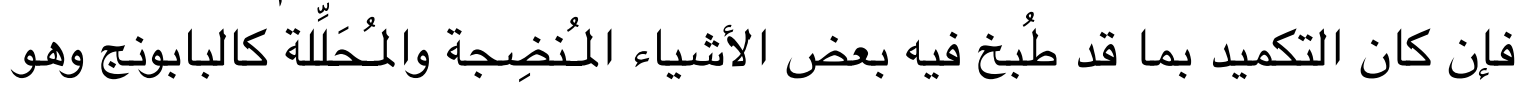

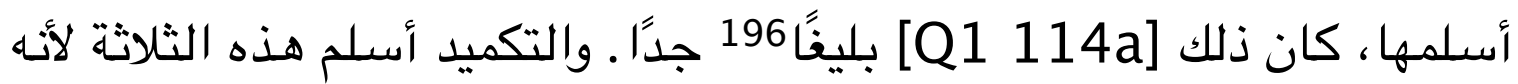

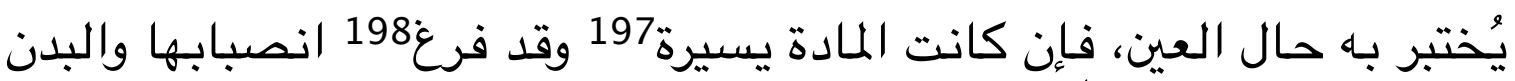

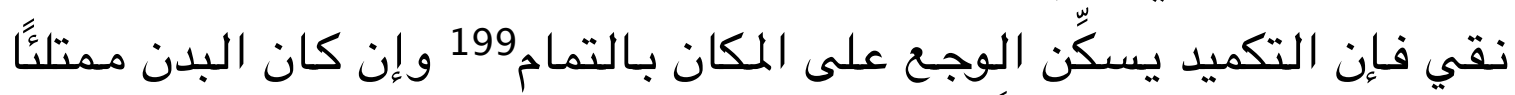

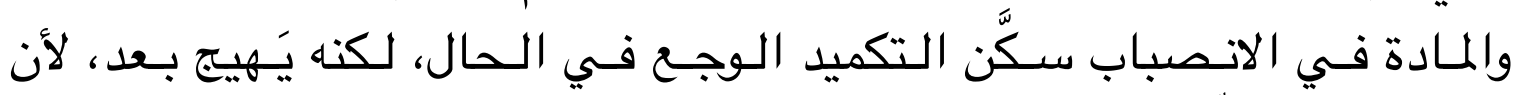
التكميد كما يُحلِّل من العضو كذلك يُسيِّّل سبيل200 الانصباب إليه، [T 107b]

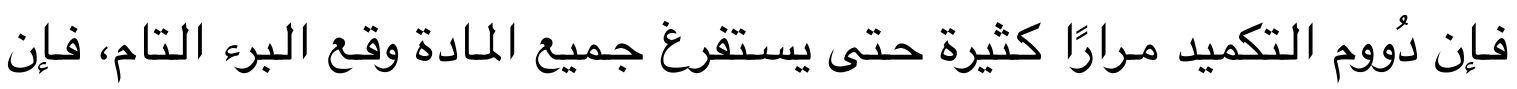

فينزعج : فيزعج Q190.

الخروج K1 اللخرو K1 MSS.

192. ويبخر Q وينخر Q1 MSS.

193 ] MSS: om. T.

194 ] MSS: بها T.

] 195 ] خاصل : MSS.

196 ] بليغًا MSS: بلغليًا K1.

] يسيرة 197 MSS: يسرة Q1.

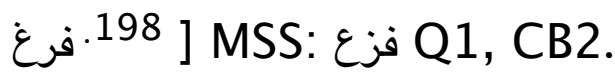

199 ب بالتمام

سيل T MSS: سيل T. 
كان [CB2 95b] في المادة مـن الكثرة مـا لا يفي التكميد باستقراغها 201،

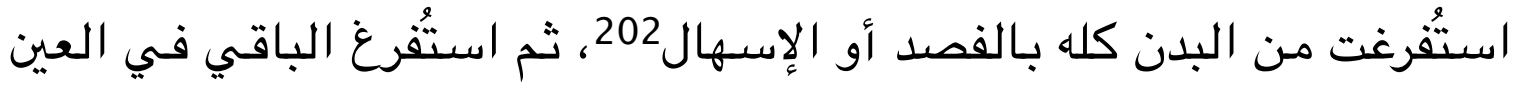

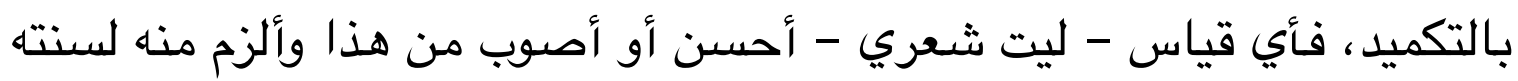
وأحرى 203 على حذوه 204.

وجالينوس يكره استعمال الأكحال الرادعة في العين، ولاسيما التي فيها

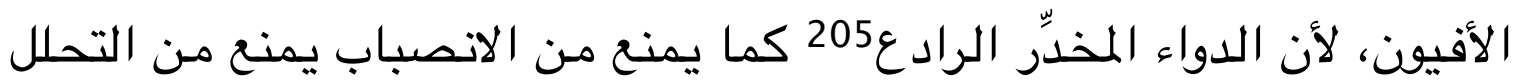

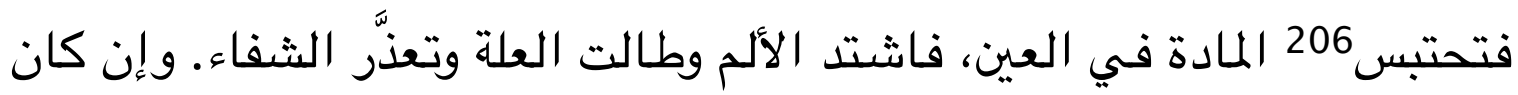
المخدر قويًا أضر بالنور الباصر وريما أعدمه أصلاً.

قال جالينوس: متى استدللت وعرفت أنه يجري إلى العين رطويات حادة

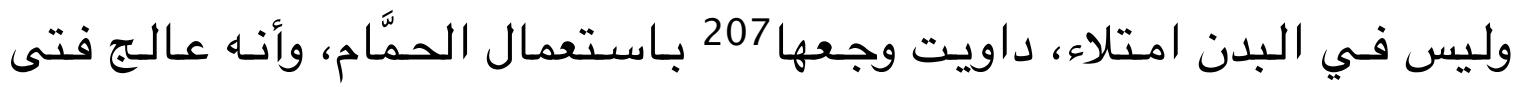

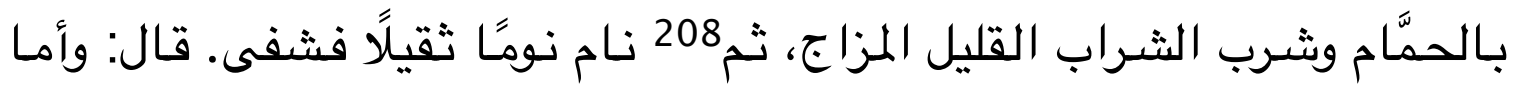

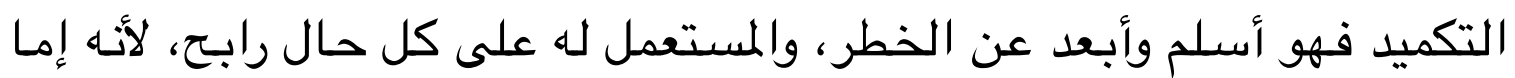

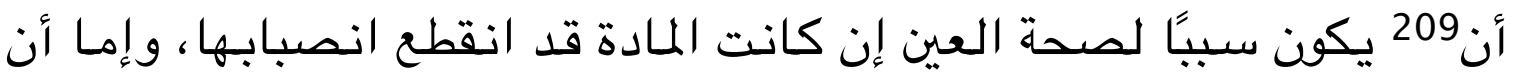

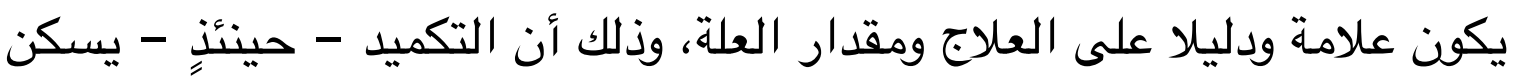

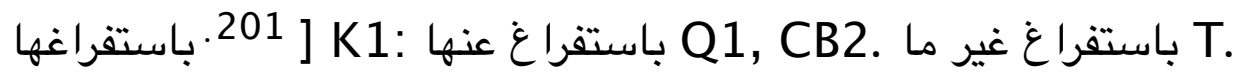

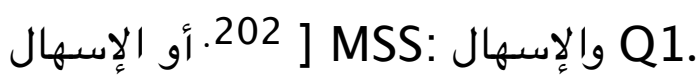

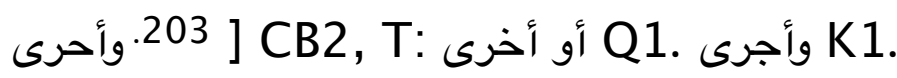

جدده CB2, T. جدده K1. جدوه Q1.

الرداع : MSS.

MSS.

T.207 ] وجعلها: MSS:

208 ] MSS: om. K1.

أن 209 ] MSS: om. T. 
الوجع في الحال غير أنها يَهيج بعد فيستدل به على الامتلاء، فيستفرغ الخلط

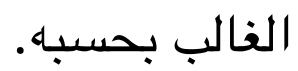

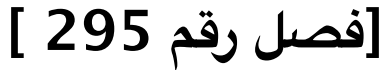

\section{قال أبقراط: اللُّنَُُّ يعتريهم خاصة اختلاف طويل.}

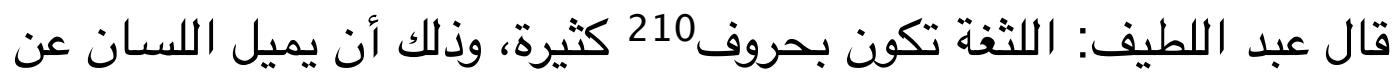
الحرف لعجزه عنه إلى الحرف القريب إليه والثبيه بـه، وقد يككن ذلك لقصن

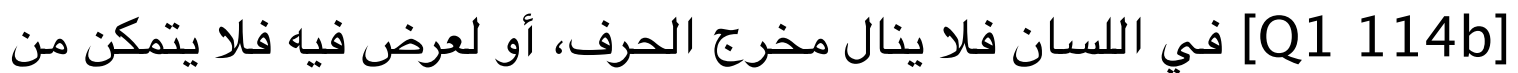

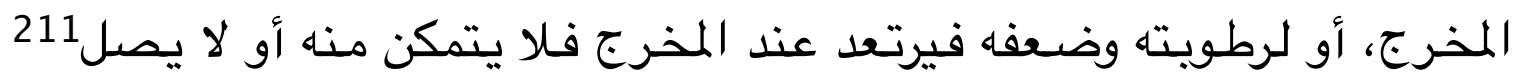

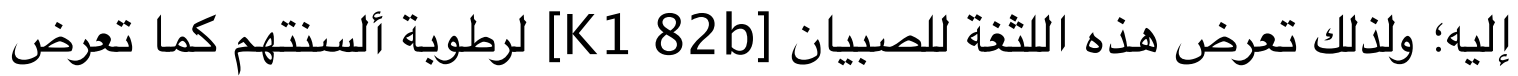

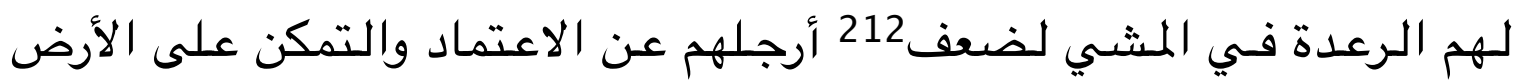

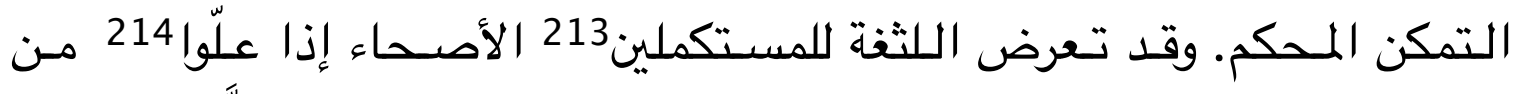

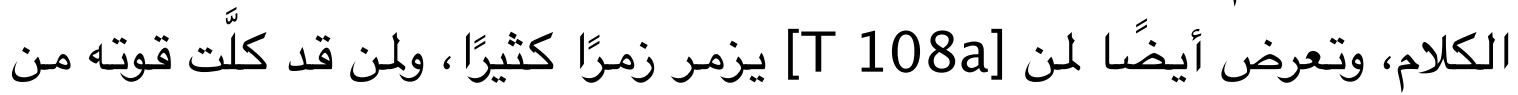

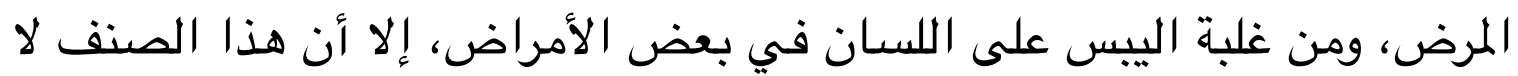

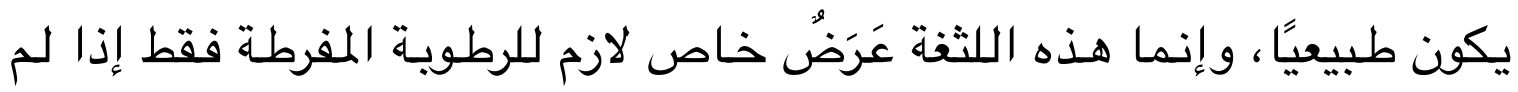

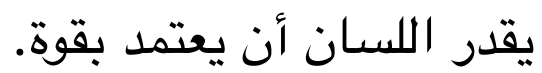

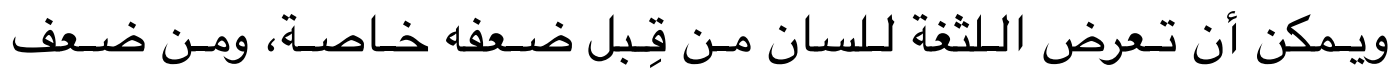
العصب الذي يأتيه من الدماع. وقد تعرض هذه اللثفة للسكران، لرطوية الدماغ وابتلاله، [CB2 96a] ولتقل الرطوية عليه، ولذلك تعرض هذه اللثة الثفة لمن كان

210 ] MSS: بحروف Q1. لحروف Q1.

K1. ولا يصل :

212 ] MSS: بضعف K1.

] للمستكلين KS1. للمستكملين K1.

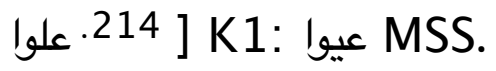




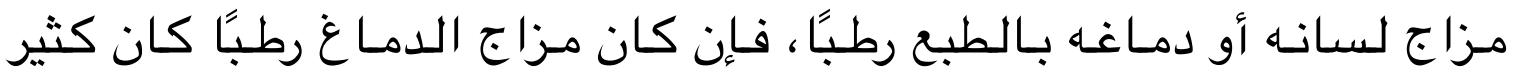

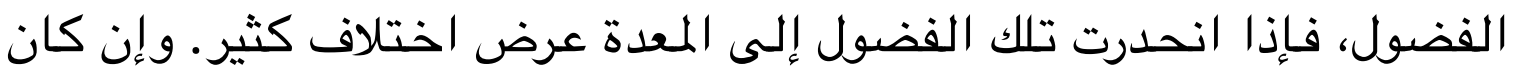

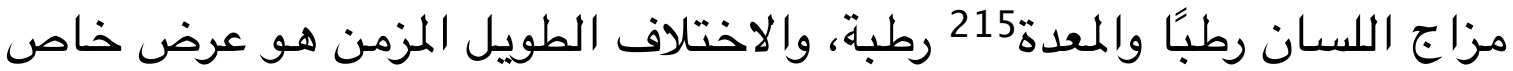

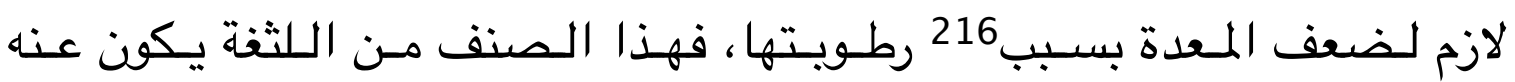

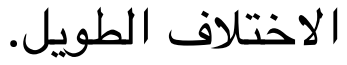

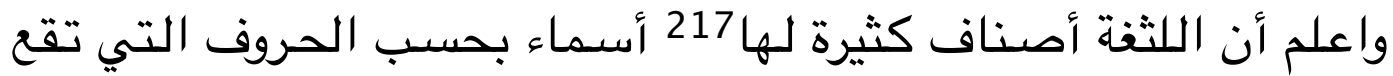
بها اللثفة. وقد يُظن أن أبقراط إنما عني اللثفة التي تكون في الراء بـأنساء

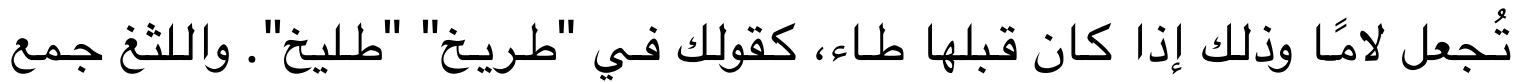

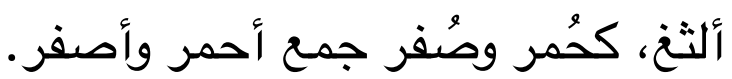

\section{[ فصل رقم 296]}

قـال أبـقراط: أصـحاب الـششاء الـحـامض لا يكاد يـيبههم ذات

الجنب.

قال عبد اللطيف: الجثاء الحامض يدل على غلبة البلغم على المزاج [115a وعلى قلة المرار وقوله: "أصحاب الجثاء" يدل به على من يعتريه كثيرًا

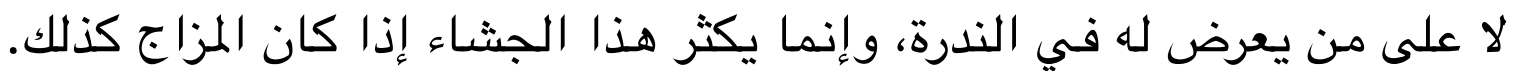

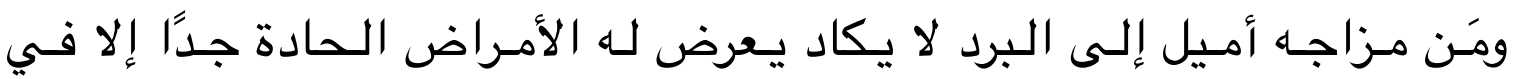

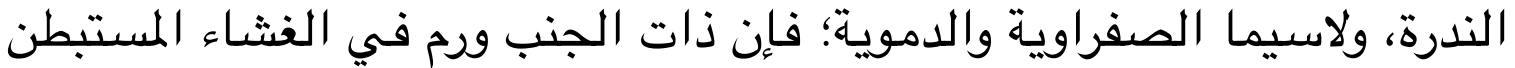

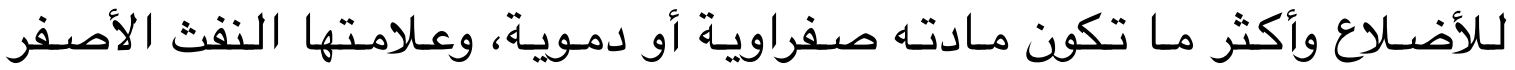

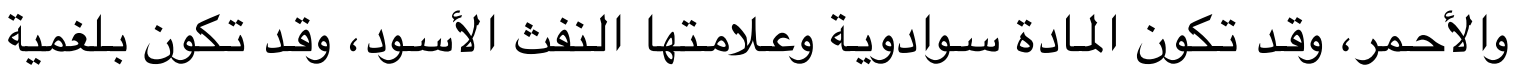
وعلامتها النفث إلى البياض، وقلما يعرض ذات الجنب عن هذه [T 108b]

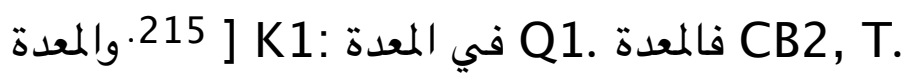

216 ] MSS: لسبب Q1.

لهما CB2.

البرء ابان : الران K1. الراء K1. CB2, الرأن CB. 
المادة. وإن كان البلغم مالحًا فكثيرًا ما يتبعه لين البطن

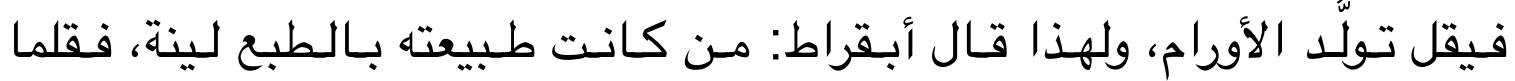

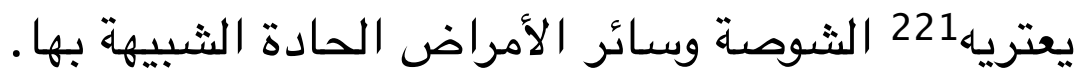

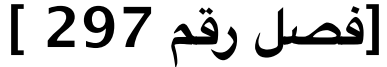

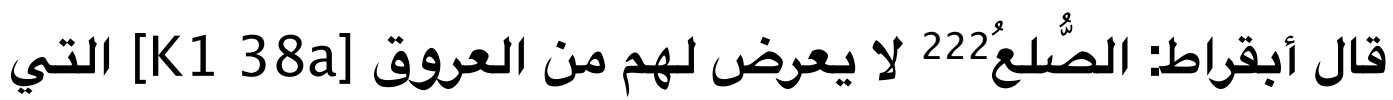

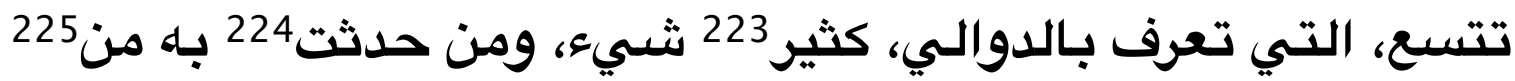
الصلع226 الدوالبي عاد شعر رأسله.

قال عبد اللطيف: إن جالينوس يرى هذا الفصل غير صحيح وأنه مفتعل

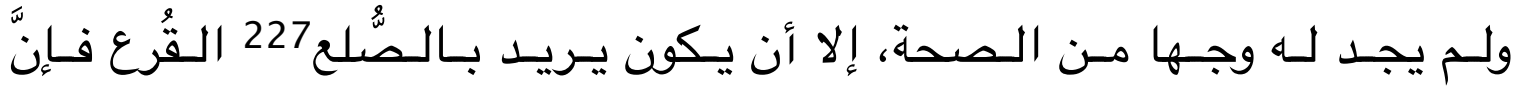

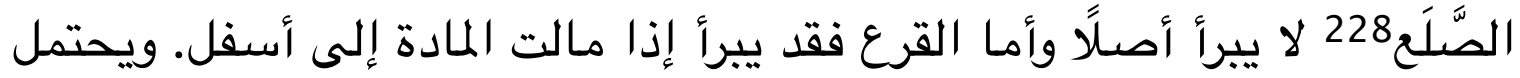

الطبع : MSS.

الطبح: K1.

221 ] MSS: يضتريه K1.

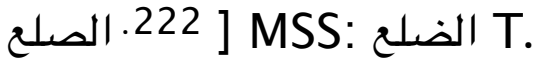

بكثير : 223 [كثير MSS.

224 ] MSS: حدثت K1.

2225 ] MSS: om. K1.

T. الضلع : T.

T بالضلع: T.

228 [ K1, CB2: الصلع Q الضلع Q1, T. 
عندي أن يكون يريد بالصُّلح229 \#من عرض له الصَّلَحم230 عن مرض، لا من كان

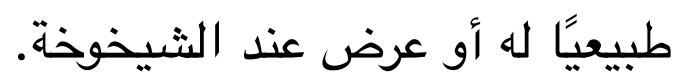

\section{]}

قال أبقراط: إذا حدث بصاحب الاستسقاء سعال، كان ذلك دليلاً رديعًا.

قال عبد اللطيف: إذا كثرت الرطويسة المائية في المستسقى حتى بـلفت قصبة الرئة، فـإنه يحدث بـ السعال، ويكون في تلك الحال قد أثـرف [CB2 96b] نفس العلة لا من سبب آخر.

\section{]}

قـال أبـقراط: نَهـدُ الـعِرق يــل عُسـر الـبول، ويـبنغي أن تقطع العروق الداخلة.

قال عبد اللطيف: [Q] [Q1 115b] إذا كان عُسر البول مـن ورم دمـوي أو من كثرة الدم فالفصد قد يحله، فلذلك ينبفي أن يزاد في الكلام "قد" فيقال232: "فصد العرق قد يحل عسر البول" حتى يفهم منه الإمكان لا الحتم.

وقوله: "ينبفي أن تقطع العروق الداخلة" أي التي في باطن الذراع، وأما

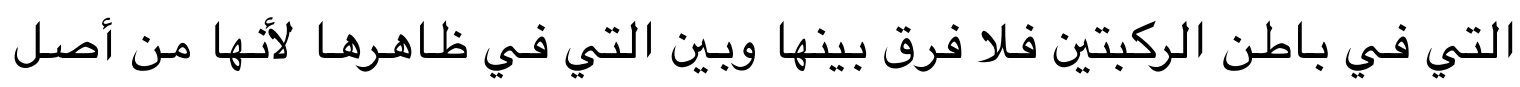
واحد، لأن الصنفين جميعا ينبتان مـن عرق واحد وهـو الذي في في بـاطن وبن الركبة،

229 K1, CB2: بالضلع Q1, T.

230 ] MSS: om. K1.

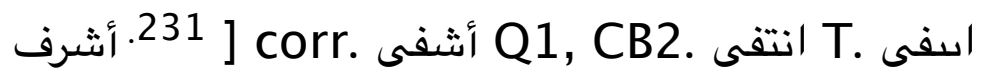

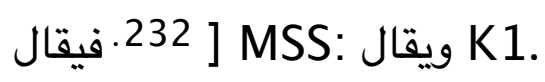


والرِّجل إنما يأتيها عرق واحد، وأما اليد فعرقان. وجالينوس لا يعتقد 233 في هذا

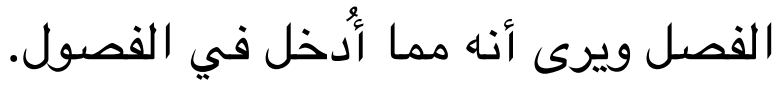

واعلم أن الداخل مـن البدن هـو الأنسى، والخارج هـو الوحشي، والعِرْق

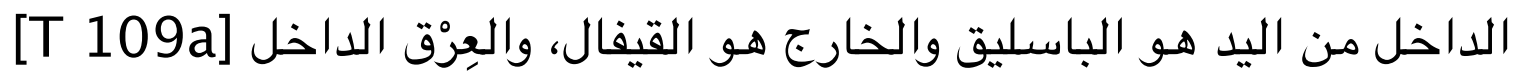

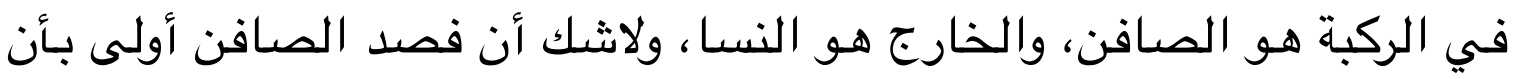

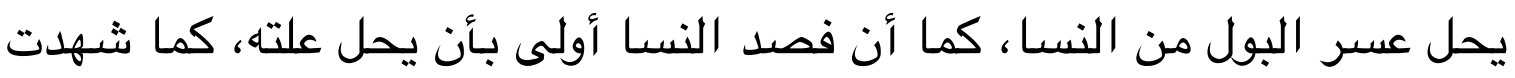
التجربة بذلك.

\section{]}

قال أبقراط: إذا ظهر الورم في الحلقوم من خـارج فيمن اعترته الذَّبحة، فإن ذلك دليل محمود.

قال عبد اللطيف: ظهور الورم إلى خارج أدل على السـلامـة، وكذلك 234 انتقاله من عضو شريف إلى عضو ليس بثريف كما تظهر الذبحة من الحلقوم

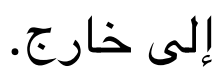

\section{]}

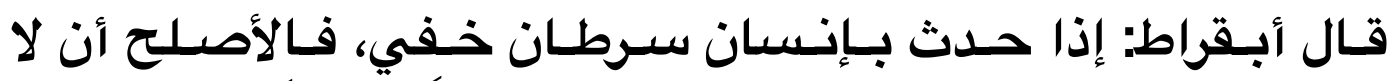

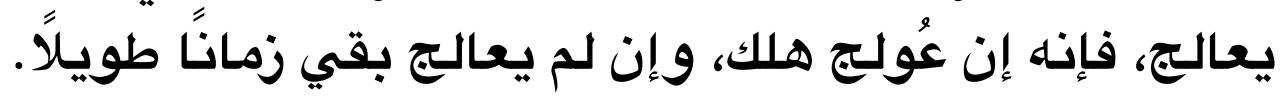

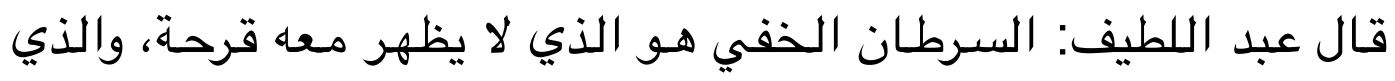

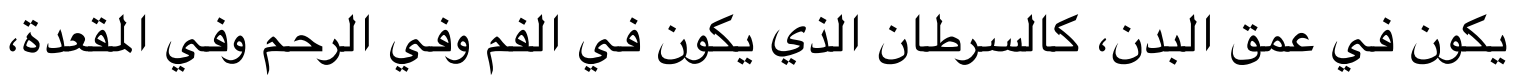

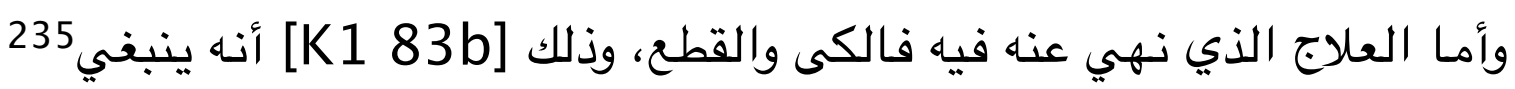

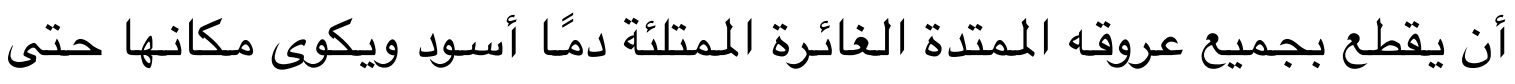

الفضل Q1. 233 ] يعتقل add.

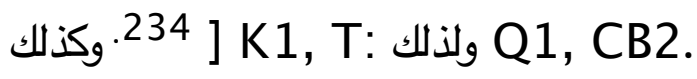

ينبني أنه : K1. 


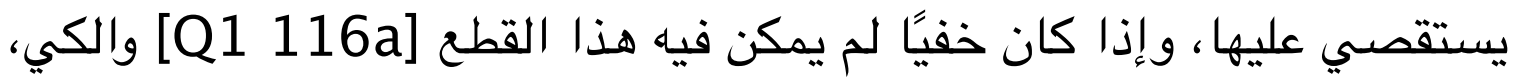

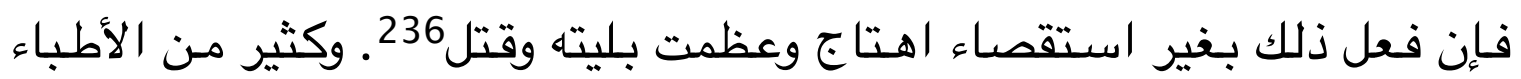

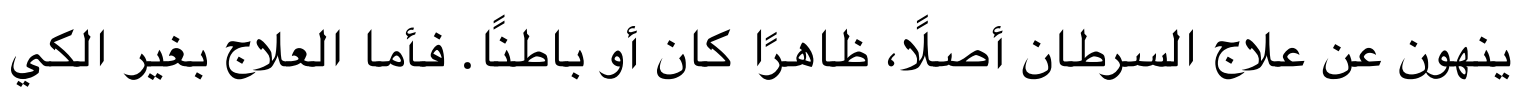

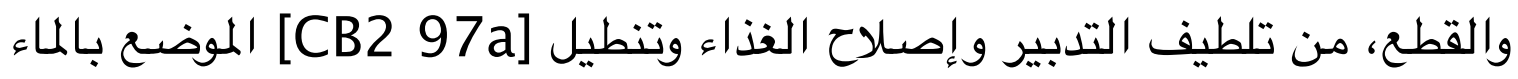
الفاتر ليسكن الألم ويغسل من

وأمـا نسخة238 أرطا ميدوروس وديسقوريدس 239 وأشـياعهما 240 فـانـما يكتب فيها هذا الفصل إلى قوله: "فالأصلح أن لا يعالج" ويسقطون ما بـا بعده.

\section{]}

قال أبقراط: التشنج يكون مـن الامتلاء ومـن الاستفراغ، وكذلك كـ

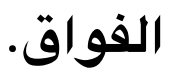

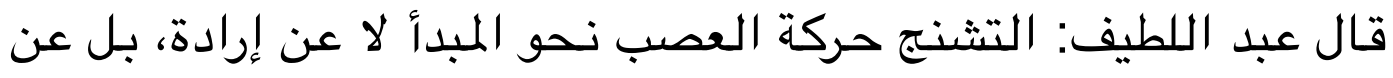

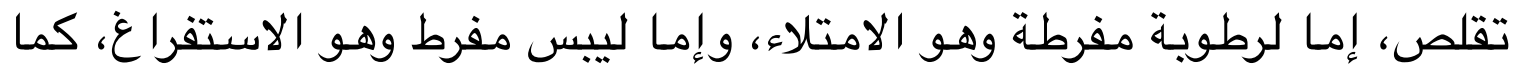

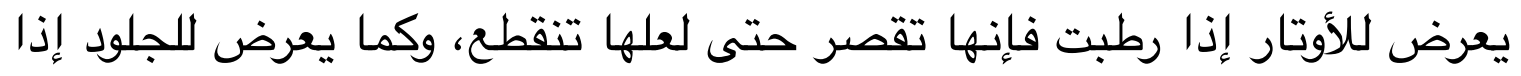

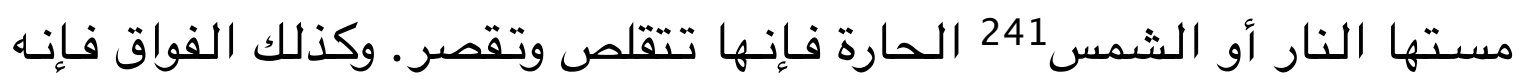

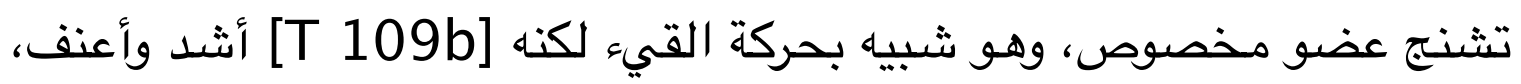

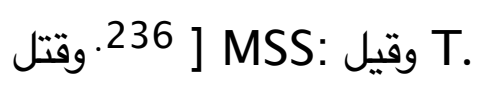

ويعان : MSS.

238 ] MSS: تنشخه Q1.

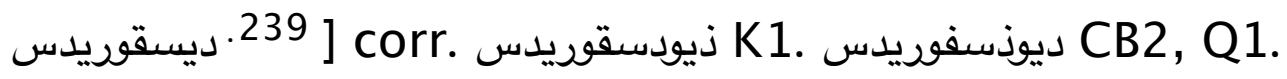

T.

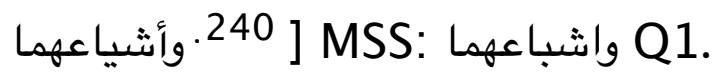

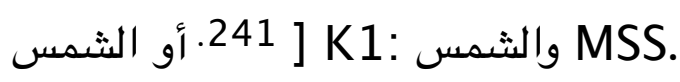


وكأن القيء تتقلص فيه242 المعدة لدفح شيء مصبوب في خوائها 243، والفواق

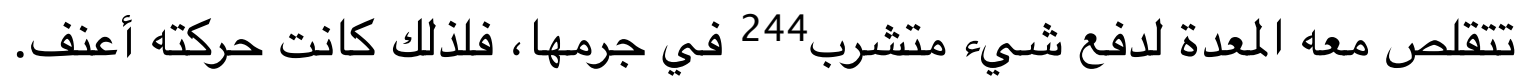

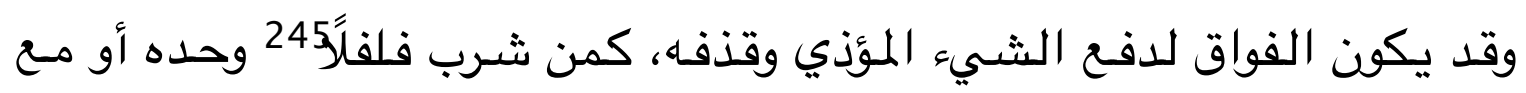

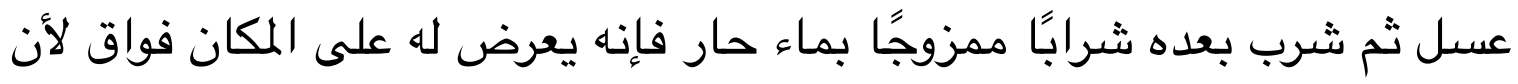

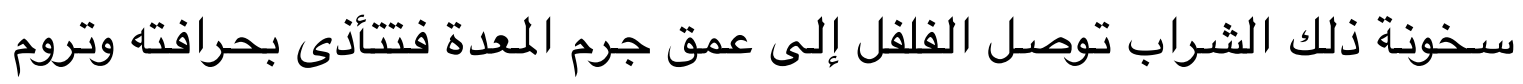

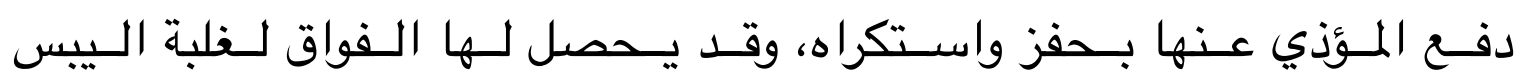

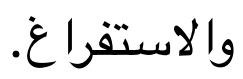

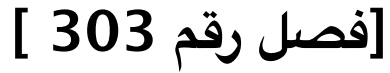

\section{قال أبقراط: من عرض لـه وجع فيما دون الشراسيف من غير ورم

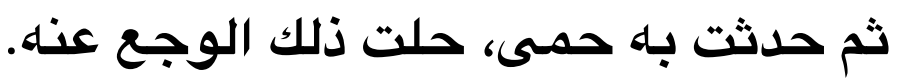

قال عبد اللطيف: الوجع لا يطلق على اللذع والحرقة، لكن إنما يطلق على

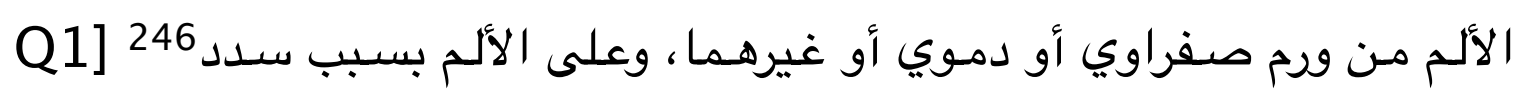

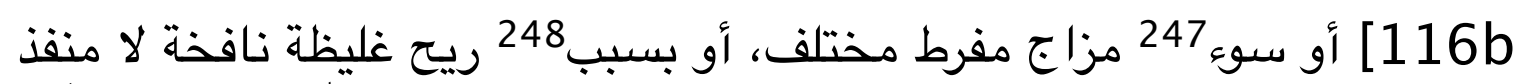

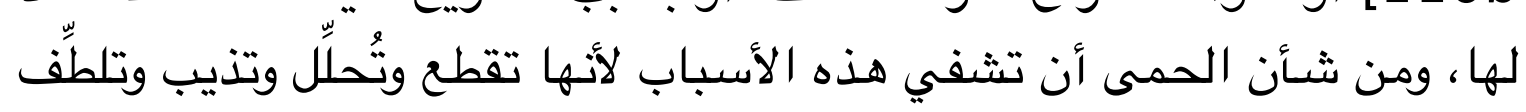

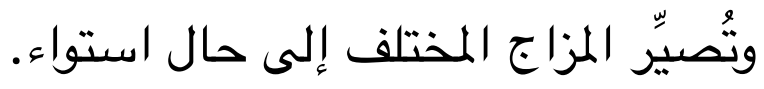

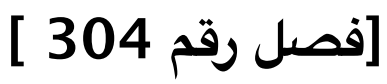

242 ] فيه KS1.

243 ] MSS: حواليها K1.

منسوب : من R1.

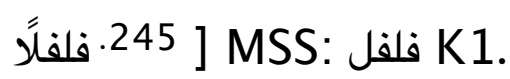

تمدد: K1.

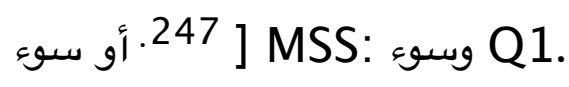

248 ] MSS: لسبب Q1. وسبب Q1. 
قال أبقراط: إذا كان موضع من البدن قد تقيَّح وليس يتبين249

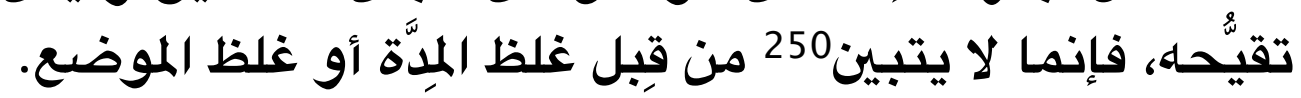
قال عبد اللطيف: إذا كانت المِلَّة غليظة صلبة لم تتبين251 تحت اللمس، كا، كان

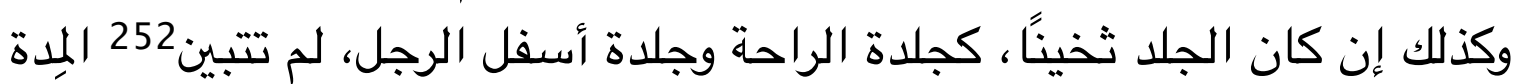
تحت اللمس لثخن الحجاب.

\section{]}

قال أبقراط: إذا كانت253 الكبد فيمن بـه يَرَقان صلبة، فذلك دليل رديء.

قال عبد اللطيف: اليرقان قد يكون على طريق البحران بأن تدفع الطبيعة

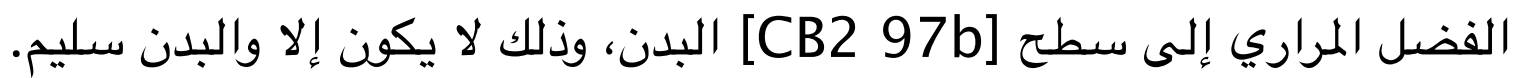

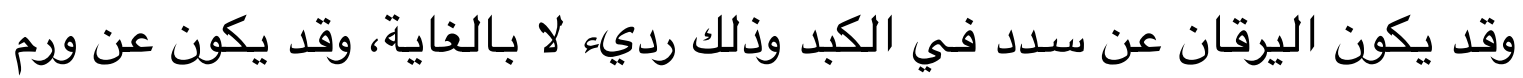

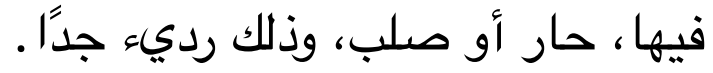

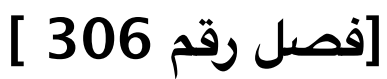

قال أبقراط: إذا أصـاب المطحول اختلاف دم فطال بـه، حدث بـه استسقاء أو زلّق الأمعاء وهلك.

قال عبد اللطيف: المطحول هو الذي في طحاله صلابة مزمنة254، فإذا

249 يتبين MSS: ينت Q1.

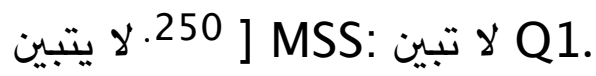

[ 251. تتبين K1, T: تبين Q1, CB2.

252 ] تتبين MSS: تبين Q1.

كان MSS.

.254 ] MSS: om. K1. 
حدث بـ اختلاف الدم وكان على جهة استفراغ تلك الأخلاط السوداوية المتشبثة [T 110a]

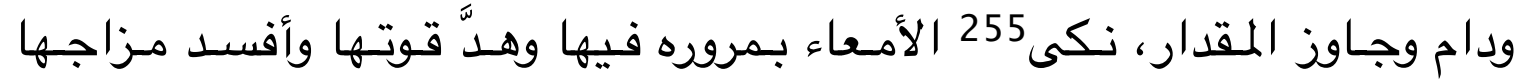

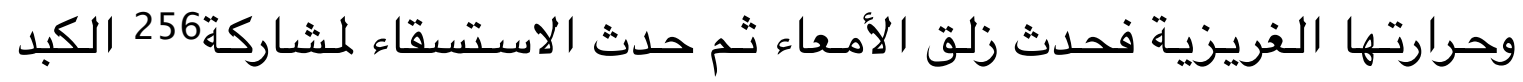

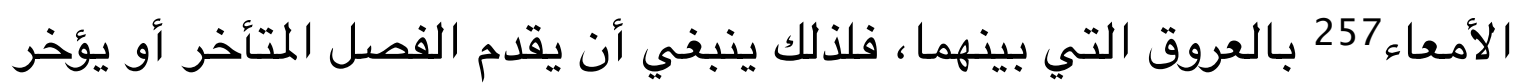

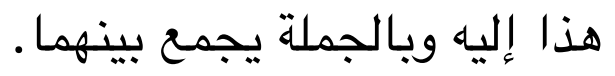

\section{]}

قال أبقراط: من حدث به من258 تقطير البول259 القولنج المعروف

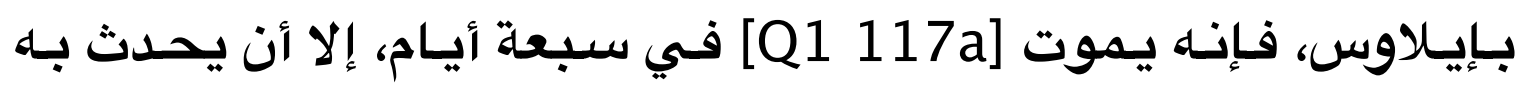
حمى فيجري منه بول كثير.

قال عبد اللطيف: إن إيـلاوس لا يـفذ مسعه شـيء إلسى أسـفل البتة وإن

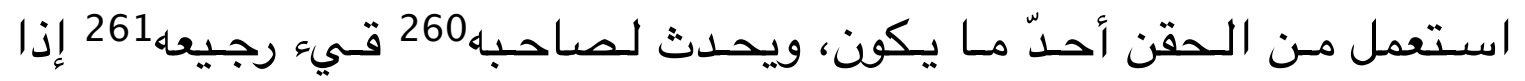

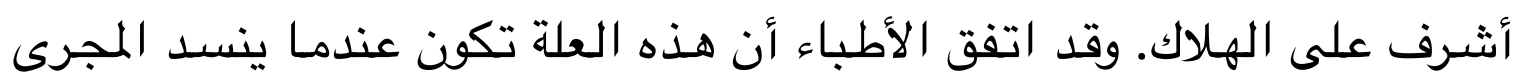

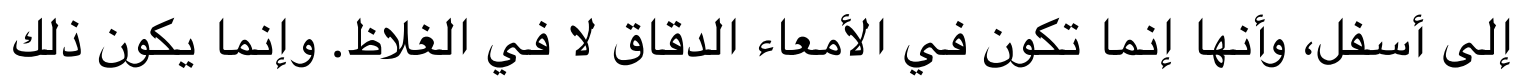

255 ] نكى لكي : لكي Q1.

وهد ] MSS: وهذا Q1.

بمشاركة 256 بمثاركة Q1.

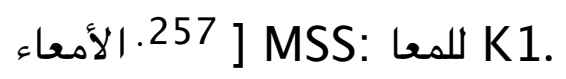

258 ] MSS: om. K1.

259 ] في البول K1.

] Q1, T: بصاحبه K1, CB2.

K1, T. 


$$
\text { من ورم أو سدة أو رجيع262 يابس صلب يسد } 263 \text { المجرى. }
$$

وجالينوس يذهب إلى أن الأولى في حدوث هذه العلة إنما هو ورم حار أو

صلب أو دبيلة وأن الرطوية الغليظة اللزجة لا ييلغ مقدارها أن تسد الأمعاء أصلاًا

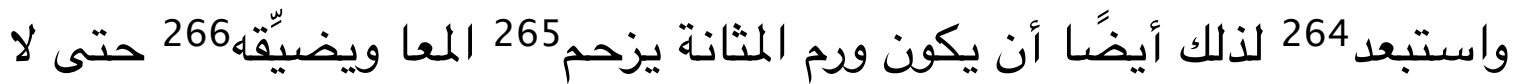

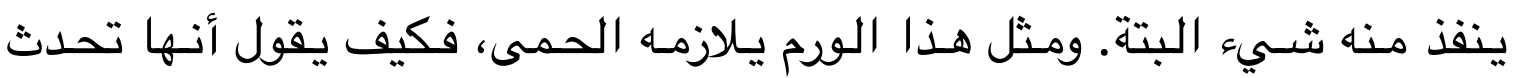
بعده. وبالجملة فإن جالينوس لا يرى صـحة هـا الفصل، ويجعله مـن جملة مـا افتعل، ويرى توجيهه بـأن يكون السبب في هذه الأعراض أخلاطًا نيئة غليظة

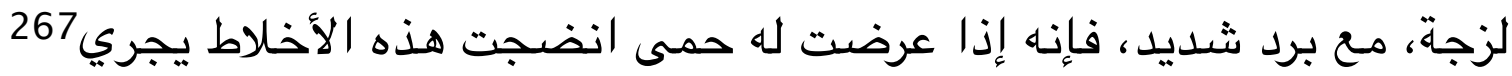
من البول شيء كثير بغتة.

\section{] فصل رقم 308 ]}

قال أبقراط: إذا مضسى بالقرحة حَوْلُ أو مُدَّة أطول من ذلك، وجب

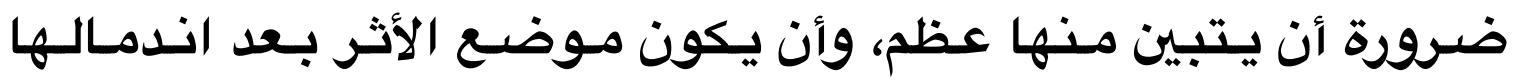

قال عبد اللطيف: [CB2 98a] القرحة تطول مدتها من قِبَلِ علة في نفس

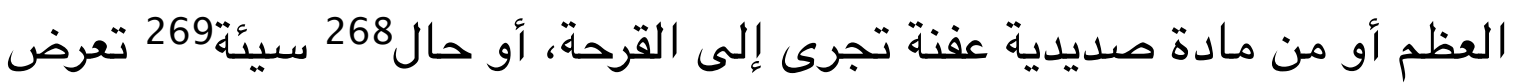

262 ] وجع : وجيع K1.

263 ] MSS: لسيد Q1.

واستعد : واستبعد K1.

265 ] يزحم CB2, Qdd. Qورم Q1, T.

MSS.

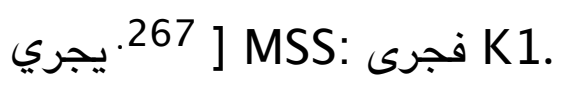

268 ] MSS: om. K1.

CB2 ييسيه CB1, T. 
فيها [K1 84b] وتنبثما20. وقد تسمى هذه القروح الساعية والآكلة والنملة

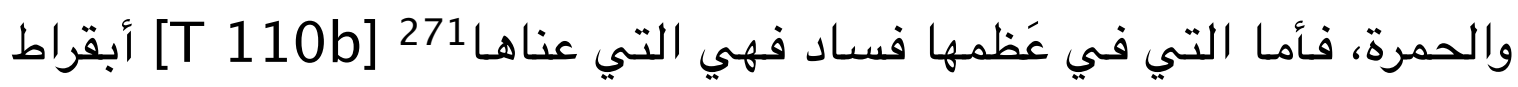

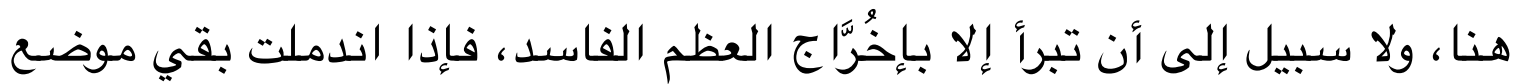

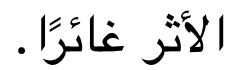

\section{]}

قال أبقراط: من أصسابته حدبـ272 من ريو أو سعال قبل أن ينبت له الشعر في العانةّ273، فإنه يهلك.

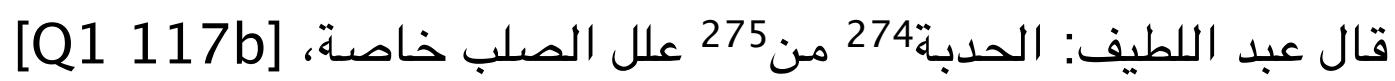

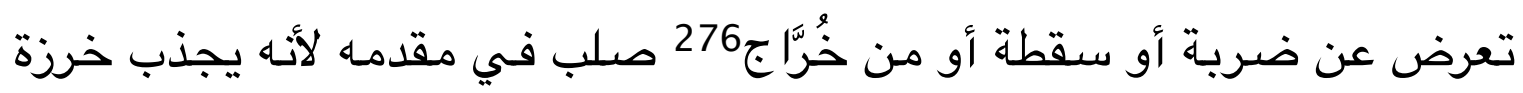

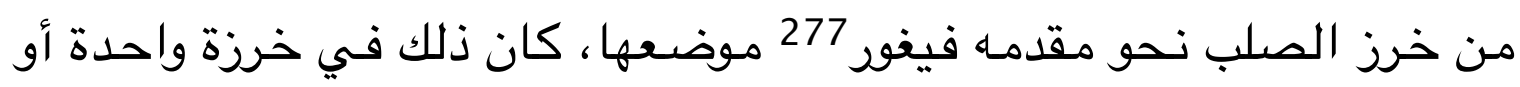

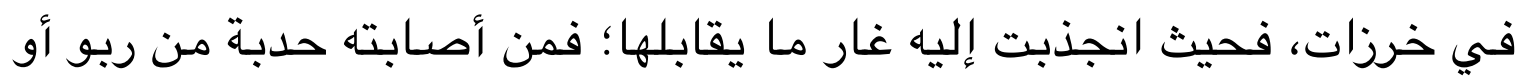

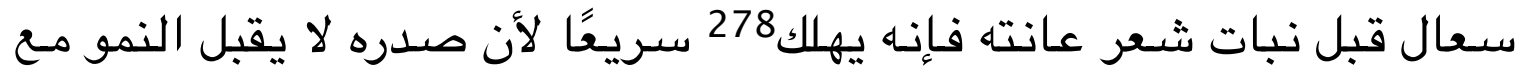

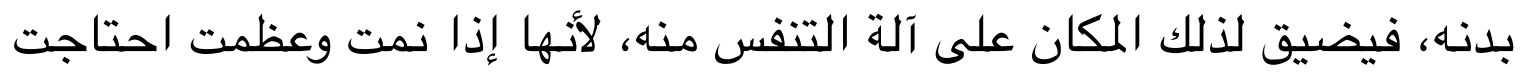

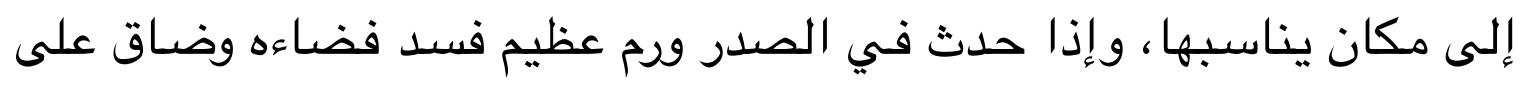

] 270. وينبت T. أو ينبث: K1, CB2.

أعناها: أع1 MSS.

272 ] K1, T: حدبة Q1, CB2.

الغاية K1 K1.

الجدبة : Q1, T.

275 ] MSS: عن K1.

K1.

فيعوز : MSS.

278 ] MSS: مهلك Q1. 
التنفس، حدث279 عنه ربو وزالت بعض خرزات الظهر، فكان من ذلك حدبة280. وإذا كان الخُرَّاج يجري منه رطويات إلى قصبة الرئة أحدث سعالًا، والسعال

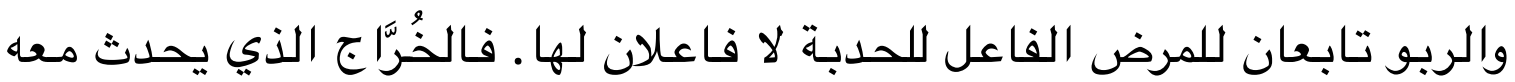
عسر التنفس إذا حدث بمن هو في النشء، فهو قتّاّل؛ وذلك أنه إذا كان فان عظيمًا

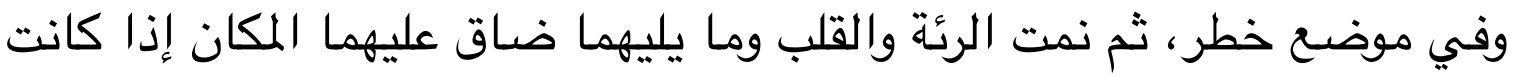

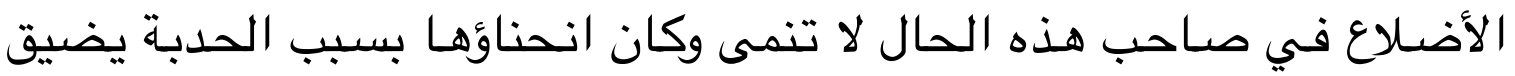

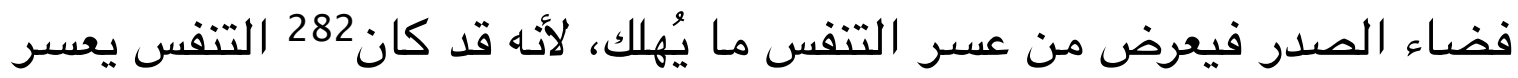

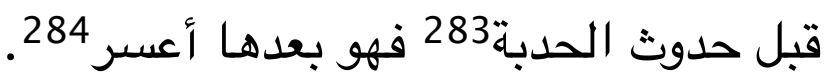

\section{]}

قال أبقراط: مَن احتاج إلـى الفهد أو شُبرب الدواء، فينبغي أن يُسقي الدواء أو يفهد في الرئيع.

قال عبد اللطيف: قوله: "من احتاج" أي لم تكن حاجته حافزة285 بل فيها

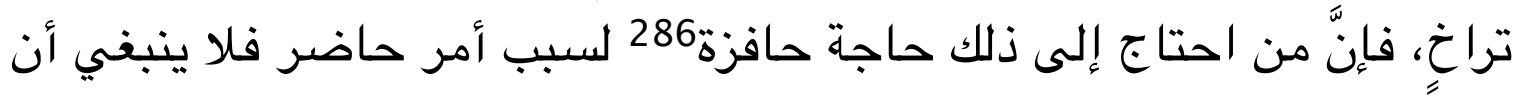

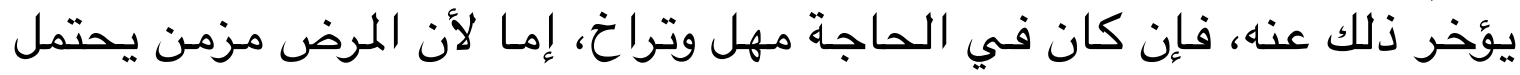

279 ] حدث ] حدب :

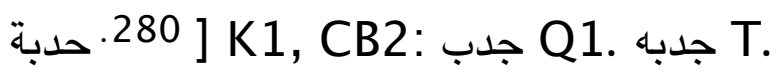

281 ـ والسعال MSS: om. K1.

كان ] كانت T.

MSS.

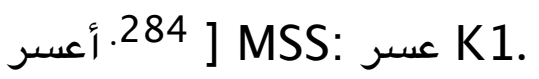

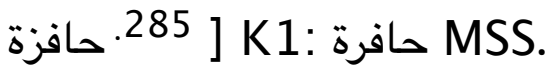

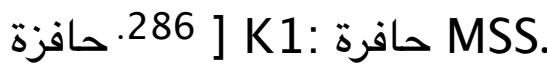


التأخير، وإما لأنه معدوم. وإنما يتقدم287 بالاستفراغ للاحتياط وخوف الوقوع

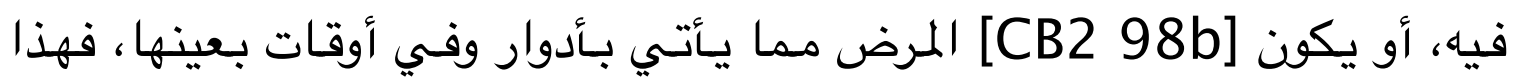
المعنى الذي [T 111a] يقصده أبقراط في قوله: من احتاج إلى الفصد. وأما

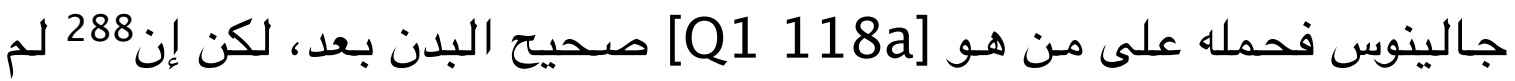

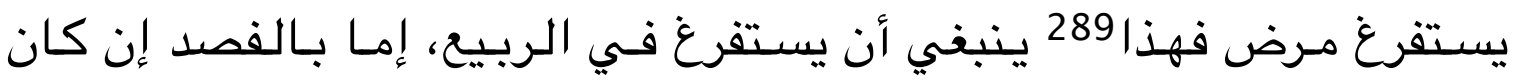

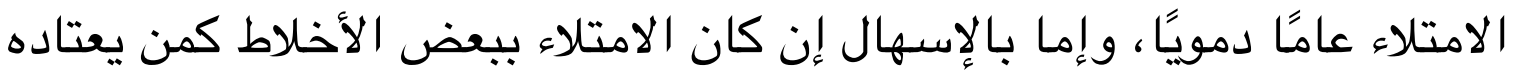

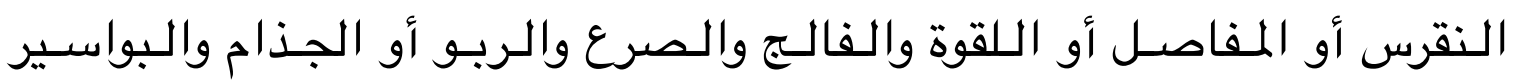

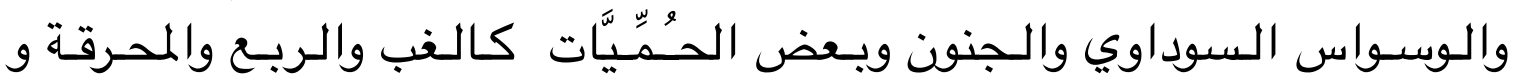

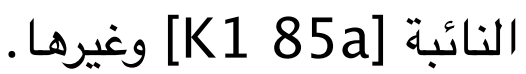

\section{]}

قال أبقراط: إذا حدث بالمطحول اختلاف دم، فذلك محمود.

قال عبد اللطيف: قد قلنا في تقسير هذا قبل، وأن هذا الدم إذا كان على إنى

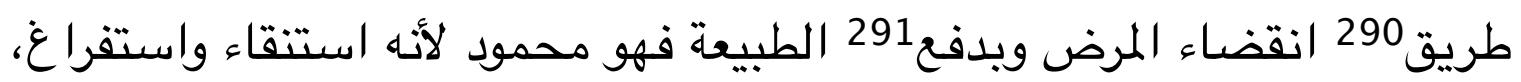

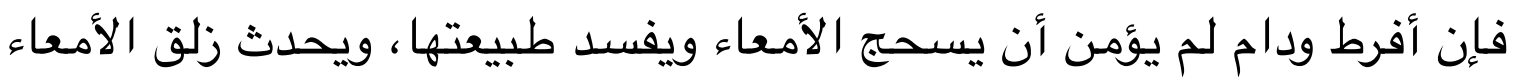
بذاته والاستسقاء على سبيل المثاركة.

\section{] 312 [صل رقم]}

قالَ أبقراط: ما كان من الأمراضٍ من طريق النَّقرس وكان معه ورم

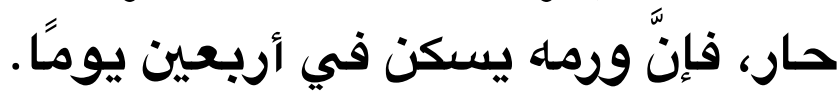

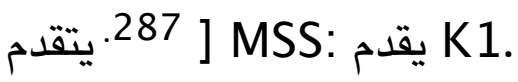

إن 288 ] MSS: om. K1.

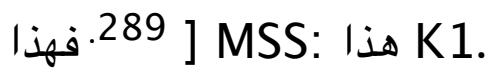

290 ] MSS: om. K1.

291 ] MSS: ويدفع Q1. 


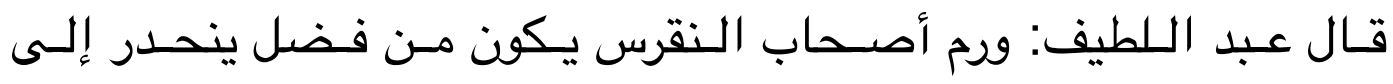
مفاصل القدمين، وأمـا العصب والأوتار فلا ترم من هوئلاء لكن يحدث فيها الوجع ورئ

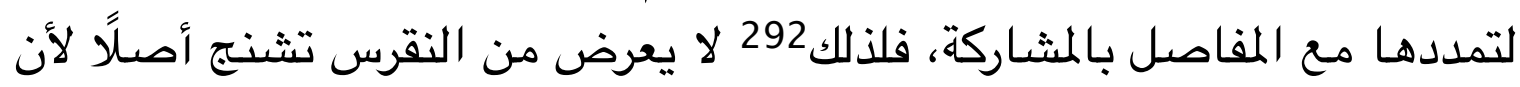

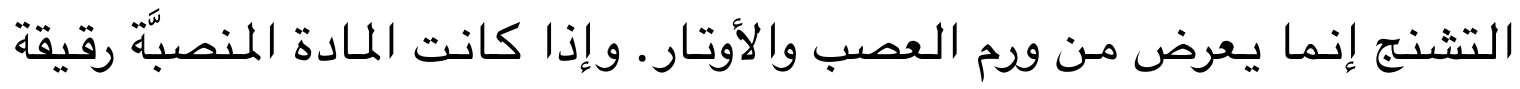

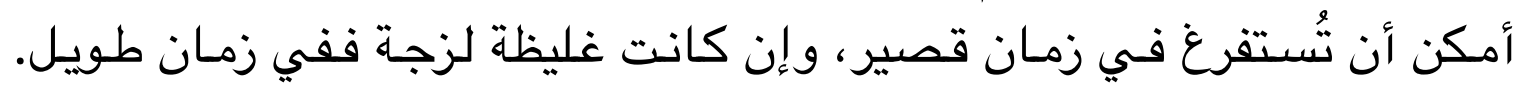

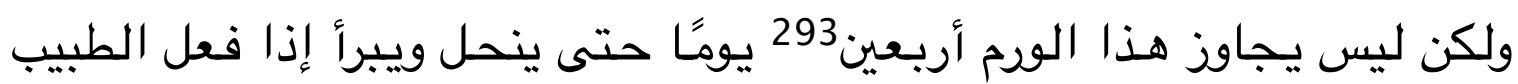

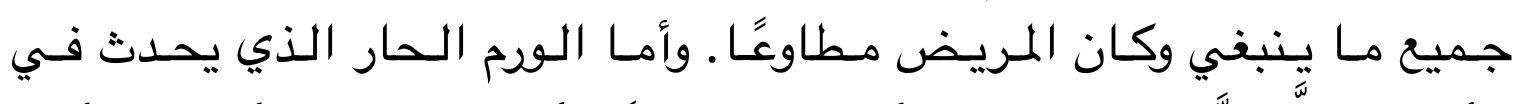

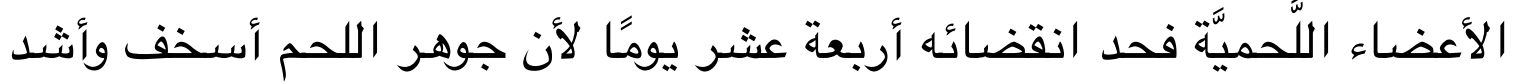
تخلخلًا. وأما ما يعرض في المفاصل من الورم فأبطأ [Q1 118b] تحلاً لأنها

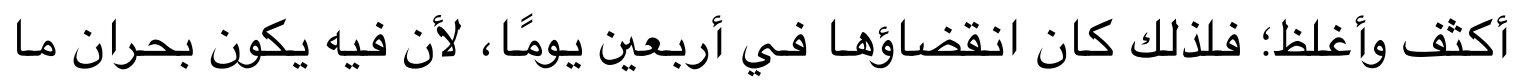

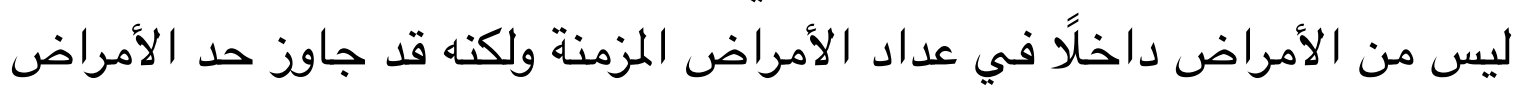

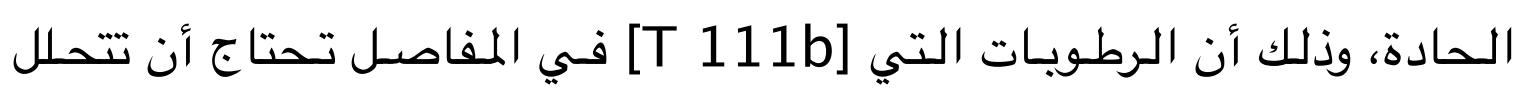
حتى تصير بخارًا وتتفذ في الرباطات294 المحيطة بالمفاصل حتى تستفرغ.

\section{]}

قال أبقراط: مَن حدث به في دمـاغه قَطع، فلابد من أن يحدث به حمى وقيء مرار.

قال عبد اللطيف: قوله: "قطع" يدل به على عظم الجراحة. ولابد أن يحدث

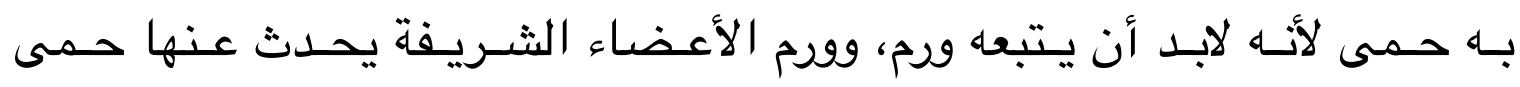

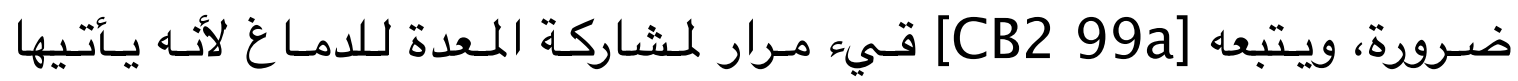

] MSS: وكذلك K1.

سنة Q1.

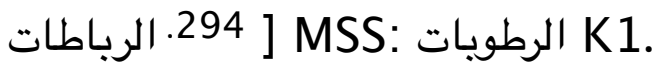


مـنه295 عصبتان، فـإنَّ مـن شـأن 296 المرار أن يتجلَّب إلى المعدة عند الصداع

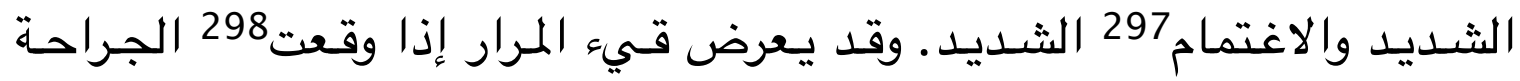

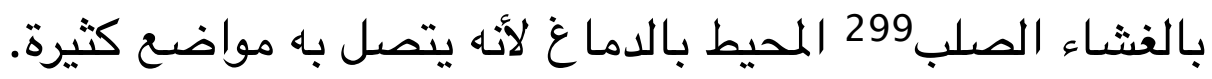

\section{]}

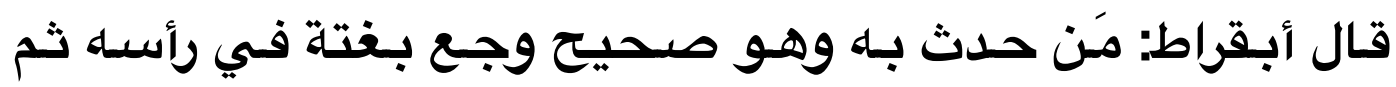
أسكت على المكان وعرض لـه غطيط، فـإنه يهلك في سبعة أيسام إن لـم تحدث به حمى.

قال عبد اللطيف: السكات300 آفة يبطل معها الحس والحركة، وقد تبطل الحركة وييقى الحس، كما قال أبقراط: أنه يعرض لبعض الناس أن أسكتوا وهـ

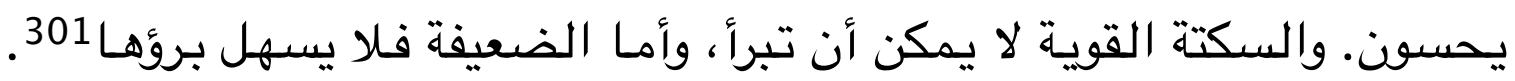
وعـلامسة السكتة [K1 85b] القويـة أن يـرض مـعها غطيط كما يـعرض لمـن

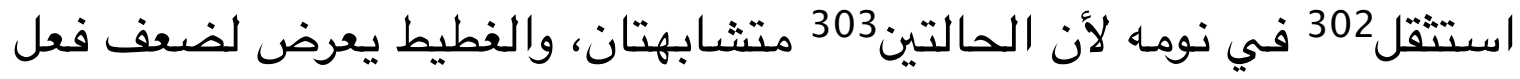
العصب. وإذا حدث بالصحيح صداع بفتة فأولى الأثياء بأن يكون سببًا ريح

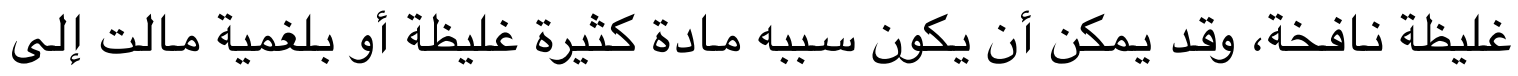

295 ] K1: om. CB2, Q1, T.

] بيان MSS بئن T.

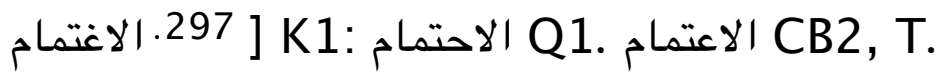

298 ] Kقعت CB2, T: دفعت CB2, Q1.

299 [ الصلب MSS: om. K1.

السكاة : MSO J السكات T.

برها : برؤ MSS.

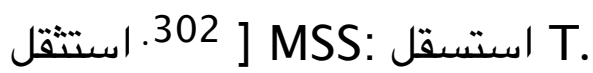

MSS. الحالين : K03. الحالتين 


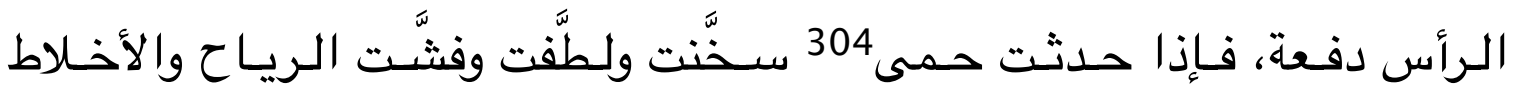

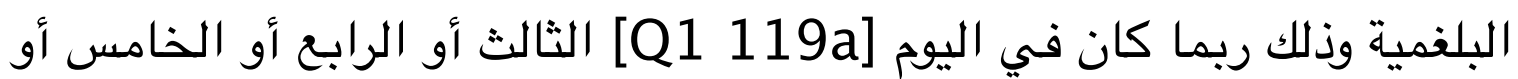

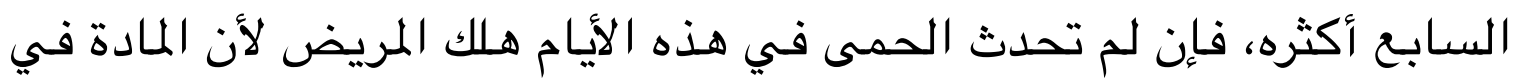
عضو شريف لا يحتمل أكثر من ذلك.

\section{] 315 [صل رقم ]}

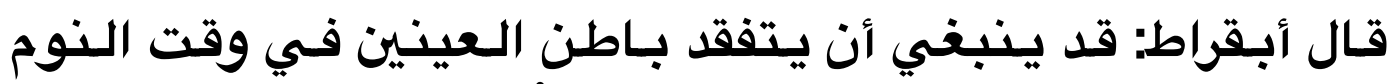

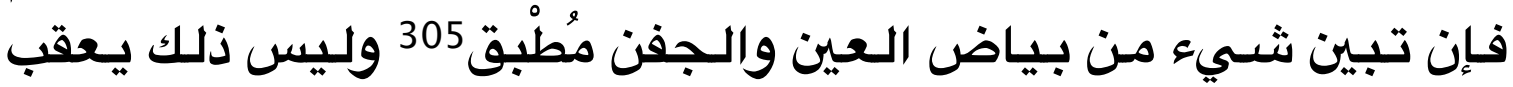
اختلاف ولا شرب دواء، فتلك علامة رديئة مهلكة جدًاً

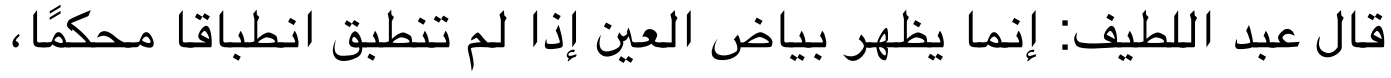

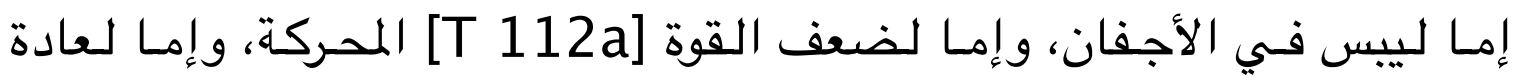

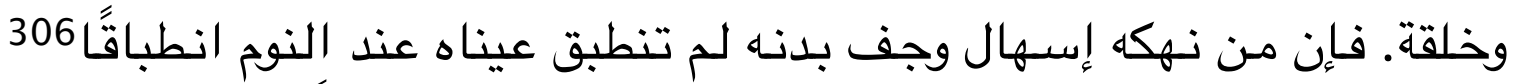

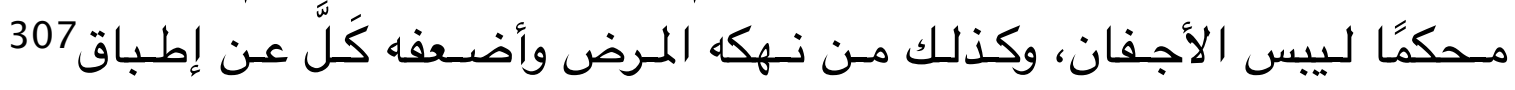

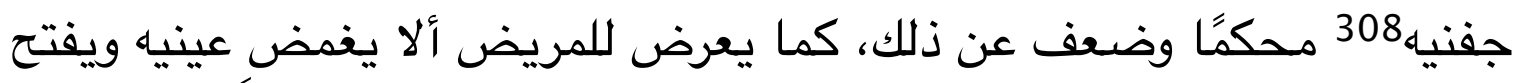

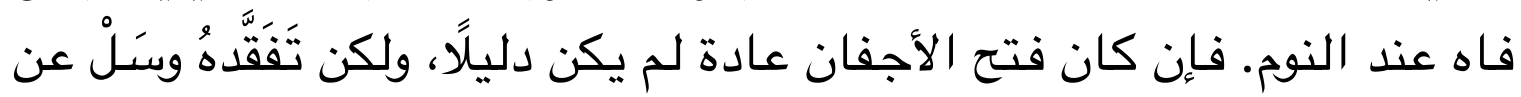

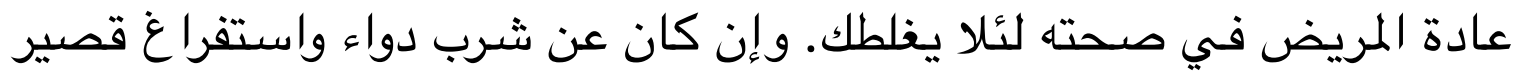

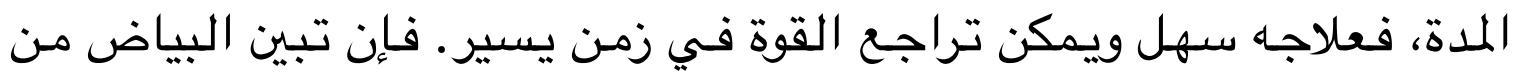

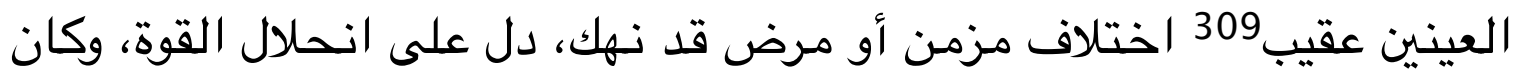

Tتى : 304 ] حمى T.

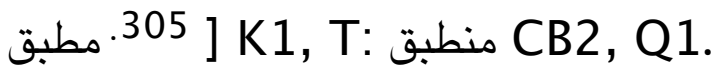

306 ] MSS: om. T.

307 ] CB2, Q1: إطباق K1, T.

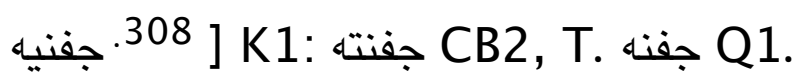

309 ] MSS: عقب T. 


\section{[CB2 99b] ]}

قال أبقراط: مـا كان من اختلاط العقل مع ضحك فهو أسلم، وما

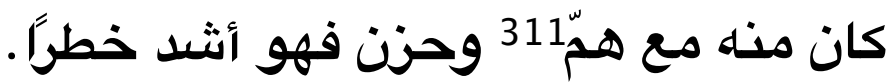

قال عبد اللطيف: ليس فـي اختلاط العقل شـيء سـليم إلا مـا كان مـع ضحك فهو أقل خطرًا ، كما 312 أن ما كان عن إقدام وتقحم فهو أشد خطرًا ، وما

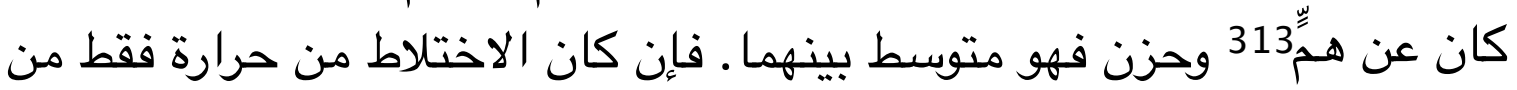

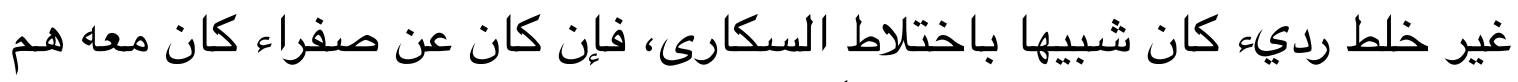
وحزن، فإن تزيدت الصفراء احتراقًا حتى تميل إلى السوداء مـال صساحبهاء 314 إلى الجنون؛ واعلم 315 أن السوداء الكائنة عن احتراق الصفراء أصعب أمرًا. وما كان من عكر الدم وغلظة فهو أقل رداءة، [Q1 119b] واسم هذا بالحقيقة خلط سوداوي، وقد يسمى مرة سوداء لأنه قليل يحترق ويصير مرة سوداء.

\section{]}

قال أبقراط: نَفَسُ البكاء فـي الأمراض الحسادة التي يكون معها حمسى، دليل رديء.

قال عبد اللطيف: قوله: "نفس البكاء" يريد صوت [K1 86a] الباكي

У.310 ] MSS: om. Q1.

311 ] K1, T: غم CB2, Q1.

كمان Q12 ] كمان Q1.

313 ] MSS: غم K1.

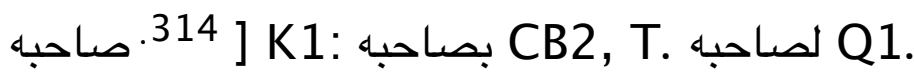

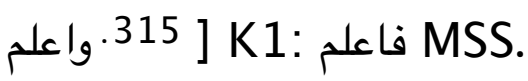


وتنفسه الذي يكون عند البكاء، وينبغي أن يكون البكاء هنا ممدودًا كالدعاء لأن

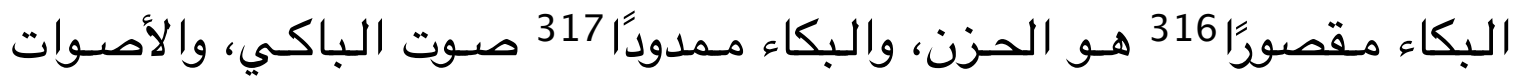

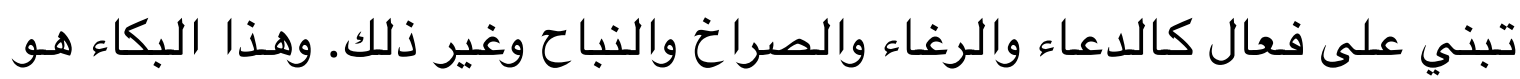

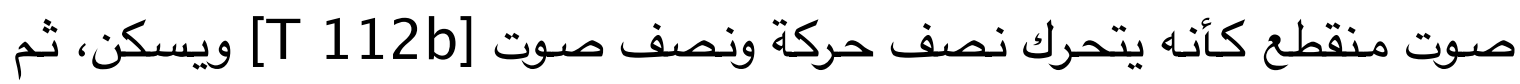
يتراجع318 بما بقى 319 وكأنه صوت متفير منقطع، وذلك قد يكون يكن ليبس الآلة أو أو

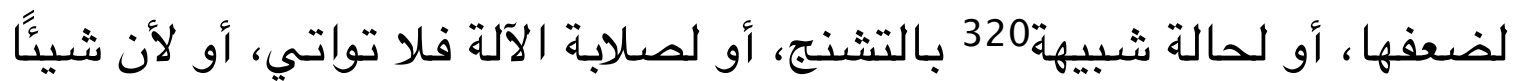

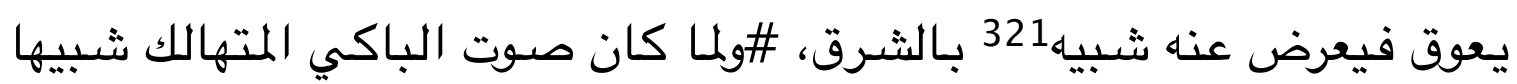

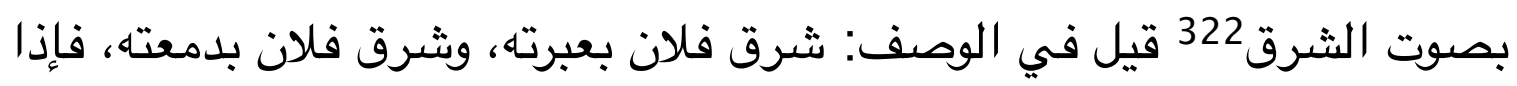

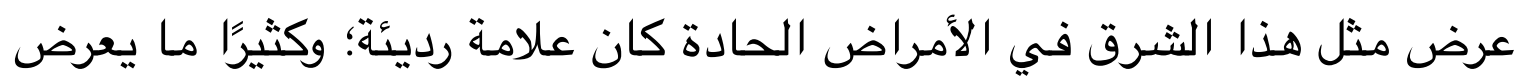

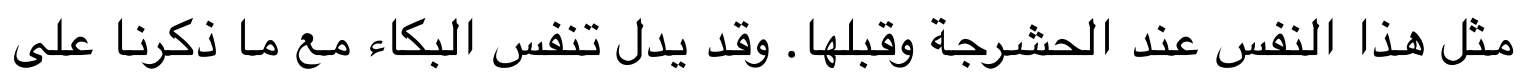

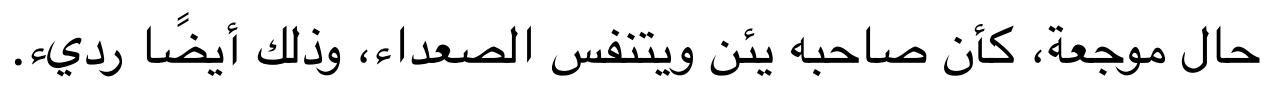

\section{]}

قال أبقراط: علل النقرس تتحرك في الريبع وفي الخريف على

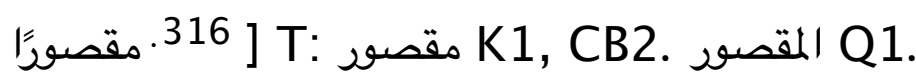

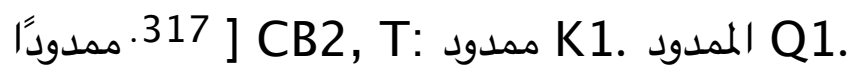

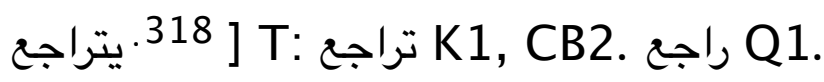

319 ] MSS: نقى K1. تراجعى K1.

K1. 320 ] MSS: شبيهة K1.

كاشبيه : كاشيه K1.

322 ] MSS: om. K1.

323 ] T, K1: om. CB2, Q1. 
قال عبد اللطيف: النقرس داخل في علل 325 أوجاع المفاصل، وأكثر مـا تتزيد علل المفاصل في الربيع، وقد ذكرهـا أبقراط في جملة الأمراض الربيعية. وقد تهيج في الخريف إذا أسيء التدبير في الصيف بالإسراف في أكل الفواكه.

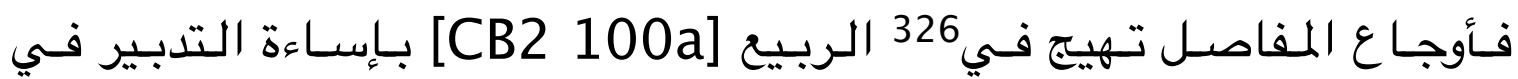
الشتاء، وسبب ذويان الأخلاط فيه حيث327 تنتقل الأبدان من الشتاء إلى ما هـ لهو

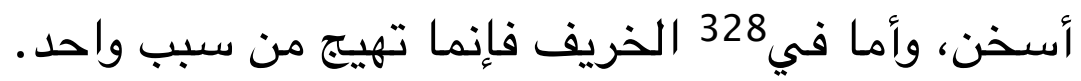

\section{]}

قـال أبـقراط: الأمـراض السوداويـة329 يـخاف مـنها أن تؤول إلىى السكتة أو الغالج أو إلى التشنج أو إلى الجنون أو إلى العمىى.

قال عبد اللطيف: [Q1 120a] أما السكتة والفالج والتشنهج والعمى فقد

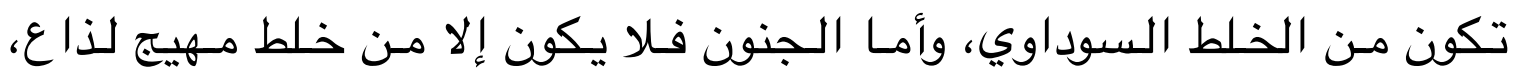

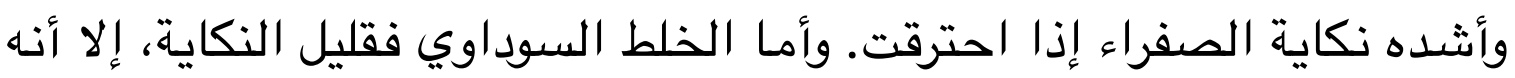
إن احترق احتراقًا شديدًا صارت له حدة خبيثة مهلكة.

\section{] فصل رقم 320 ]}

MSS.

325 ] MSS: om. T.

326 ] K1: pm. CB2, Q1, T.

327 ] Mيث. MSS: om. Q1.

328 ] MSS: om. K1.

السوداوي السود MSS السوداوية T. 
قال أبقراط: السكتة والغالـج يحدثان خـاصسة فيمن كان 330 سنه فيما بين الأربعين سنة إلى الستين سنة.

قال عبد اللطيف: إنما يعرض في هذه السن السكتة والفالج الكائنان عن

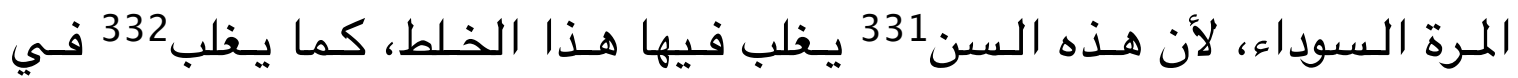
الخريف، ولاسيما من جاوز الستين سنة.

\section{]}

\section{قال أبقراط: إذا بدا الثرب فهو لا محالة يعنن.}

قال عبد اللطيف: الثرب هـو333 الغشثاء المجلِّلِ 334 للمعدة ذهما دونهها. وقوله: "إذا بـا" [T 113a] معناه إذا ظهر وخرج مـن الفشـاء الآخر المـدود

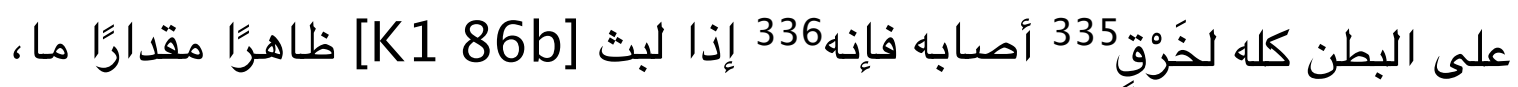

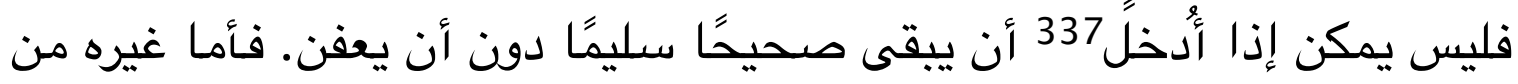
الأعضاء كالأمعاء وزوائد الكبد فإنها قد تلبث ظـاهـرة مدة مـا قبل أن تبرد بردًا

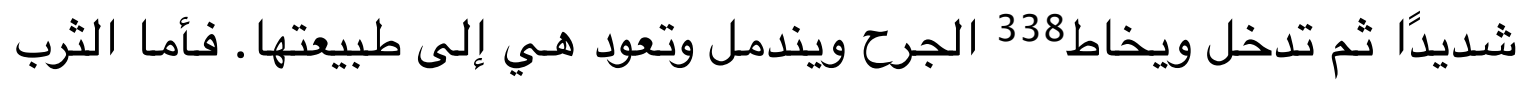

كان K كانت K 1.

السن اللسن السن: 331 Q1.

332 ] T: om. K1, CB2, Q1.

333 ] MSS: om. K1.

] MSS: المحلل K34. المجلل K1.

335 ] CB2, Q1: بخرق K1. لحرق T.

] add. إذا لبس ظاهرًا مقدارًا ما البس ظاهرًا Q136 فإنها Q

MSS. دخل : 337 [أدخل

ويخلط K1. 
فإن أدخل على فوره فقل يسلم، وإن بقي أدنى مدة عفن ولم يقبل العلاج339،

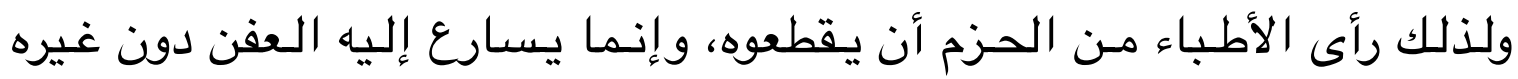

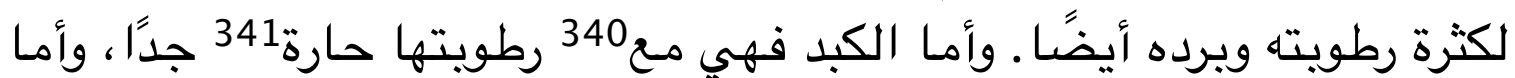
المعا ففيه يبس، فلذلك أسرع العفن إلى الثرب دونه ونئ وليره.

\section{]}

قال أبقراط: من كان به وجح عرق النَّسَا وكان343 وركه ينخلع ثم

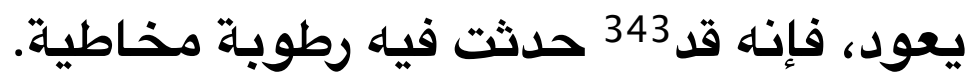

قال عبد اللطيف: الرطوية المخاطية هـي الكيموس البلغمي اللزج مع رقة، فإذا ابتل بـه مفصل الورك استرخى، ولذلك ينخلح344 العظم [Q1 120b] من

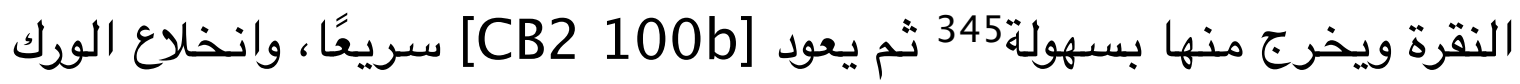
هو انخلاع مفصله من رأس الفخذ.

\section{]}

قال أبقراط: من اعتراه وجـع في الورك مزمن فكان وركه ينخلع، فإن رجله كلها تضمر ويعرج إن لـ يكو.

قال عبد اللطيف: هذا الفصل متصل بما قبله، وذلك أن من صسارت وركه تتخلح

الصلاح : T39 العلاج T.

2. 340 ] MSS: om. T.

341 ] MSS: حادة K1.

342 ] MSS: فكان K1.

343 ] MSS: om. K1.

] يخلع : ينح Q1.

K1. بسولة K1. 
لكثرة الرطوية المخاطية ودام استرخاؤها فإن الرّّجل تعرج وتضمر لقلة اغتذائها

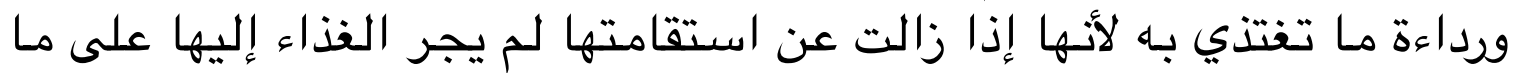

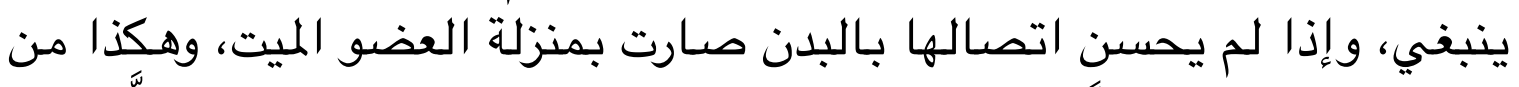

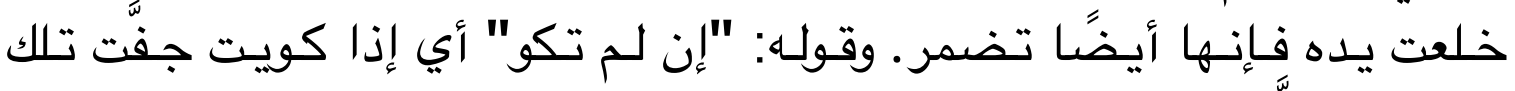

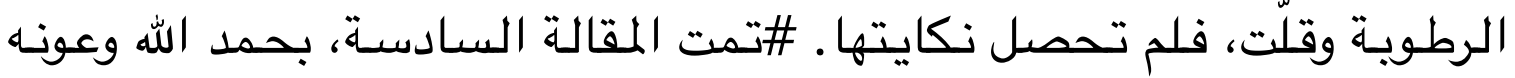
وحسن توفيقه 346.

تمت المقالة السادسة والحمد : K1 [36. تمت المقالة السادسة بحمد الله وعونه وحسن توفيقه CB2, Q1. om.T. 